\title{
JOURNAL
}

OF THE

ARNOLD ARBORETUM

$\begin{array}{lll}\text { Vol. XXV APRIL, } 1944 & \text { NUMBER } 2\end{array}$

\section{PLANTS OF COAHUILA, EASTERN CHIHUAHUA, AND ADJOINING ZACATECAS AND DURANGO, V ${ }^{1}$}

\author{
Ivan M. JoHNSTON
}

\section{LORANTHACEAE}

Phoradendron lanceolatum Engelm. Mem. Am. Acad. 4: 54 (1849).

CoAhuila: Sierra Gloria, Marsh 1872; Hillcoat Canyon, west of Buena Vista Ranch, July 13, 1938, Marsh 1332; Sierra Madera, Cañon Pajarito, on white oaks, Muller 3201.

Known only from eastern Coahuila and northern Nuevo Leon. The type was collected on Quercus by Gregg (no. 255), Feb. 11, 1847, at Rinconada, just east of the Coahuila-Nuevo Leon boundary along the road between Saltillo and Monterrey. The species is readily recognized by its very elongate glabrous leaves $5-9 \mathrm{~cm}$. long.

Phoradendron tomentosum (DC.) Engelm. in Gray, Jour. Boston Soc. Nat. Hist. 6: $212(1850)$.

Viscum tomentosum DC. Prodr. 4: 670 (1830).

Phoradendron Greggii Trel. Monog. Phorad. 36. t. 32 (1916).

Vernacular Name: Injerto.

Coahuila: Rancho Falcon, 12 mi. west of Berrendo, Wynd 732; Sierra Madera, Cañon Pajarito, on Acacia and other legumes, Muller 3202; Puerto San Lazaro, Wynd $\mathcal{E}$ Mueller 133; Cañon de Jara, on Acacia, Johnston 8838; 60 mi. west of Cuatro Cienegas, on Prosopis, White 1957; 5 mi. west of Americanos, on Prosopis, Muller 3292; east of San Antonio de los Alamos, on Prosopis, Johnston 8278; near Santa Elena, Sierra Cruces, on Forestiera, Johnston \& Muller 229; 6 mi. northwest of El Oro, road to Sierra Mojada, White 1976; 30 mi. south of Sierra Mojada, Wynd 770. ZaCATECAS: Cedros, Lloyd \& Kirkwood 15.

This is the common Phoradendron, usually found on Prosopis and Acacia, in the broad valleys and in the lower canyons on the plateau of northern Mexico, ranging from northern San Luis Potosi and Zacatecas north into trans-Pecos Texas. The type was collected in Dec. 1827 "supra Mimoseas" by Berlandier (no. 1364) near Catorce in northern San Luis Potosi. Phoradendron Greggii, based upon collections from Prosopis and other

${ }^{1}$ The third paper in this series, in which the treatment of the monocotyledons was completed, appeared in Jour. Arnold Arb. 25: 43-83 (Jan. 1944). The fourth part, covering the families Saururaceae to Urticaceae, will appear later this year. 
legumes at Rinconada, just east of the Coahuila boundary on the road between Saltillo and Monterrey, appears to be a synonym.

In our area the species seems readily recognizable by its thickish orbicular-ovate to ovate-oblong leaves and the grayish velvety indument on the spikes and younger leaves and branches. In trans-Pecos Texas it is difficult, if not impossible, to separate it from plants collected on Juglans, Celtis, Quercus, and Prosopis, which appear to be pubescent phases of $P$. Engelmanni. Most of the typical P. tomentosum from Texas comes from the Big Bend area, and grows on Prosopis and Acacia.

Trelease, Monog. Phorad. 36, reports material of $P$. Greggii from Jimulco (Pringle 845) and Peña (Purpus 1106). The collection from Gomez Farias (Palmer 291) which he refers to P. thyrsoideum probably also belongs to $P$. tomentosum as here accepted.

Phoradendron Engelmanni Trel. Monog. Phorad. 35 (1916).

Coahuila: Rancho Babia, Marsh 1216; along arroyo southwest of Sierra Azul, Rancho Buena Vista, July 8, 1938, Marsh 1262, 1263.

The above collections have the green, inconspicuously pubescent stems and thin leaves of typical P. Engelmanni, a plant growing on Ulmus, Prosopis, and Quercus about the eastern and southern escarpments of the Edwards Plateau in Texas.

Phoradendron macrophyllum (Engelm.) Cockerell, Am. Nat. 34:293 (1900),

Phoradendron Cockerellii Trel. Monog. Phorad. 38. t. 36 (1916).

Under the name $P$. Cockerellii, Trelease, 1. c., reports a collection of the species from Juarez, Chihuahua. A completely glabrous form of the species occurs on Populus, Salix, and Fraxinus along the Rio Grande in southern New Mexico and along the southern boundary of Texas as far down the river as Presidio. The large broad bright green usually completely glabrous leaves, glabrous spikes, and its favoritism for trees growing in river-bottoms usually permit its recognition. It grows from trans-Pecos Texas to Arizona and in adjoining Mexico.

Phoradendron Coryae Trel. Monog. Phorad. 43. t. 44 (1916).

Phoradendron Wilkinsoni Trel. Monog. Phorad. 44. t. 45 (1916).

VERnacular Name: Injerto.

CoAhuila: Sierra Gloria, Marsh 1896; Hillcoat Canyon, west of Buena Vista Ranch, July 13, 1938, Marsh 1334; Hillcoat Mesa lying west of Encantada Ranch, July 25, 1938, Marsh 1469; Sierra Madera, Cañon Pajarito, on white oaks, Muller $3173 A \mathcal{E} B$. Chinuahua: Sierra Organos, LeSueur 1307.

A well marked species, readily recognizable by its dense close persistent indument of very numerous minute stellate hairs which form a crustose covering on its branches and thick leaves. It ranges from trans-Pecos to Arizona and northern Mexico, almost exclusively on oaks. The type of P. Wilkonsoni was collected in the Sierra Santa Eulalia, April 3, 1885, by Wilkinson.

Phoradendron flavum Johnston, Jour. Arnold Arb. 24: 93 (1943).

Coahuila: Sierras Negras, $9 \mathrm{~km}$. south of Parras, on Quercus, Stanford et al. 210 ; hills $11 \mathrm{~km}$. northeast of Jimulco, on Quercus, Stanford et al. 71.

This species is otherwise known only from the type, which was collected 
on oaks near Durango City by Palmer (no. 777). A plant with a tawny indument and thick dark green leaves.

Phoradendron pauciflorum Torr. Pac. R. R. Rep. 4: 134 (1857).

Phoradendron saltillense Trel. Monog. Phorad. 27. t. 16 (1916).

Coahuila: Sierra del Carmen, Cañon Sentenela, Wynd $\mathcal{E}$ Mueller 625; Sierra del Carmen, Aug. 21, 1936, Marsh 567, 569; Hillcoat Canyon, west of Buena Vista Ranch, July 13, 1938, Marsh 1292; Sierra Madera, Cañon del Agua, on Cupressus, Muller 3220; San Antonio de las Alanzanas, on cedars, Aug. 31, 1848, Gregg 399 (isotype of P. saltillense); Sierra Negras, $9 \mathrm{~km}$. south of Parras, on Juniperus, Stanford et al. 149.

I am unable to distinguish the plant of eastern Coahuila from $P$. pauciflorum, a species of western North America ranging from Oregon to Baja California and Arizona. The species is not known from Texas, New Mexico, or Chihuahua. In our area it parasitizes Juniperus and Cupressus. These same genera, and also Abies, are the hosts of the plant in the western United States.

Phoradendron Bolleanum (Seem.) Eichl. in Mart. Fl. Bras. 52: 134 (1868).

Chinuahua: Sierra Santa Eulalia, on Juniperus, April 1885, Pringle 256.

A species of the Sierra Madre Occidental, ranging from Durango north into Arizona and western Texas. The species has been repeatedly collected on Juniperus and Arbutus.

Arceuthobium vaginatum (H.B.K.) Eichl. in Mart. Fl. Bras. 5²: 105 (1868).

Coanuila: Sierra del Pino, on Pinus arizonica, Johnston \& Muller 591; General Cepeda, Nelson 6730.

A Mexican species extending north into the United States to Arizona, Colorado, and trans-Pecos Texas. In northern Mexico and the United States it is usually confined to yellow pines.

\section{SANTALACEAE}

Comandra pallida A. DC. in DC. Prodr. 14: 636 (1857).

Coahuila: Sierra del Carmen, Cañon Sentenela, Wynd $\mathcal{E}$ Mueller 543; Sierra del Carmen, Aug. 26, 1936, Marsh 599. Chinuahua: Road between Samalayuca and El Paso, April 17, 1852, Wright 1784.

A parasitic herb widely distributed in the United States reaching its southern limit in our area.

\section{RAFFLESIACEAE}

Pilostyles Thurberi Gray, Mem. Am. Acad. II. 5: 326 (1854).

Apodanthes Pringlei Wats. ex Robinson, Bot. Gaz. 16: 83 (1891).

Pilostyles Pringlei Rose, Contr. U. S. Nat. Herb. 12: 264 (1909).

Coahuila: Hac. Mariposa, east slope of Sierra de Puerto Santa Anna, on Dalca, Wynd $\mathcal{F}$ Mueller 256; Sierra Fragua, high western ridge north of Puerto Colorado, on Dalea, Johnston 8783 .

The collection from the Sierra Fragua is a female plant and is very similar to the type of $P$. Thurberi from Dalea in southwestern Arizona. The material from Hacienda Mariposa is a male plant. Its flowers are more elongate and lighter than are the female flowers. It seems probable that only a single species of this remarkable stem-parasite infects shrubs of the genus Dalea and that in all probability P. Covillei Rose (from Texas), 
P. glomerata Rose (Puebla), P. Palmeri Rose (San Luis Potosi), and $P$. sessilis Rose (Hidalgo) are all phases of $P$. Thurberi. These species are known only from shrubby species of Dalea. A well-marked species, $P$. globosa (Wats.) Solms-Laub., a parasite on Bauhinia, is known from Monterrey. It should be looked for in Coahuila.

\section{ARISTOLOCHIACEAE}

Aristolochia longiflora Engelm. \& Gray, Jour. Boston Soc. Nat. Hist. $5: 259$ (1845). Coahuila: Muzquiz, 1935, Marsh 11.

A plant of south-central and southern Texas, reaching its southern limit in eastern Coahuila.

Aristolochia Marshii Standl. Field Mus. Publ. Bot. 17: 238 (1937).

Coahuila: Muzquiz, April 1938, Marsh 1143.

The type of this species was collected near Muzquiz, by Marsh (no. 10) in the spring of 1935. It is known only from near Muzquiz and in the vicinity of Monterrey. The stems are elongate, slender, and apparently twining.

Aristolochia lassa Johnston, Jour. Arnold Arb. 21: 255 (1940).

Coahuila: Saltillo, common on bottom-lands, 1898, Palmer 187 (TyPE); Saltillo, 1909, Nil 10 (US); Carneros area, 1880, Palmer'1183.

A well-marked species known only from the collections cited above. This species is probably most closely related to the Texan $A$. Coryi, from which it differs in its abruptly bent rather than nearly straight perianth-tube, its lance-ovate rather than elliptic limb, and the somewhat retrorsely ascending or appressed hairs on the stem.

Aristolochia Coryi Johnston, Jour. Arnold Arb. 21:256 (1940).

This species ranges from west-central Texas (Mitchell, Tom Green, Edwards, and Kinney Counties) west to Brewster County, Texas, where it has been collected at various stations in and around the Chisos Mts. In 1928 E. J. Palmer (no. 34225) collected it in clefts of rocky cliffs in the Grand Canyon of the Rio Grande near Castellan. At this station, now usually known as Santa Helena Canyon, A. Coryi makes its closest known approach to the range of $A$. Wrightii, for that more western and southern species has been collected on Mesa de Anguila, the mass of limestone through which the Rio Grande has cut Santa Helena Canyon.

Aristolochia Wrightii Seem. Bot. Voy. Herald 331.t. 72 (1856).

Aristolochia Wrightii var. texana Johnston, Jour. Arnold Arb. 21 : 254 (1940).

Vernacular names: Yerba del Indio; Pimpinela.

CoAhuila: Sierra Hechiceros, Cañon Indio Felipe, Stewart 150; Sierra Moreno, southeast of Castillon, Johnston $\mathcal{G}$ Muller 1262; vicinity of Santa Elena, east base of Sierra Cruces, Johnston $\mathcal{E}$ Muller 232, Stewart 228, 1925; Sierra Cruces, Cañon Tinaja Blanca, Johnston \& Muller 292, Stewart 325, 574, 633; near San José, southeast base of Sierra Cruces, Johnston \& Muller 1001; Sierra Planchada, Cañon Gringo, Stewart 1045; Sierra Mojada, April 19, 1892, Jones 52 (US) ; San Antonio de los Alamos, Johnston $\mathcal{E}$ Muller 902; Puerto San Lazaro, Muller 3044; Rancho Las Uvas, east side of Valle Acatita, Stewart 2689; Torreon, Feb. 1905, Purpus 1057; 6 mi. west of Viesca, Johnston 7746. Chinuahua: Rancho San José del Progreso, south end of Sierra Seca, Stewart 
2329; Rancho El Pino, southeast of Sierra Rica, Stewart 2385; 8 miles northwest of Cruces, Johnston 7986 (type of var. texana) ; 3 mi. south of Pirámide, Johnston 8114; $71 / 2$ miles south of Pirámide, Johnston 8099; 2 miles east of El Coyote, Johnston $\mathcal{E}$ Muller 1407; Sierra Encinillas, near Fierro, Stewart 800; rocky hills near Chihuahua, April 1885, Pringle 9; west base of Sierra Santa Eulalia, Stewart \& Johnston 2107; northwest of Chihuahua, Aug. 1, 1936, LeSueur 601; Rosatilla Dam east of Meoqui, LeSueur 602; Parral, Oct. 4, 1936, Collins \& Kempton (US). Durango: Mapimi, 1898, Palmer 540.

I am accepting $A$. Wrightii Seem. as typified by the plant illustrated by Seemann, that is, apparently Seemann 2175 from near Durango. This form of the species is exemplified by Palmer 314 and 328 from central Durango, a fact I previously did not fully recognize, since I failed to realize that Seemann's illustration of his plant is several times natural size. The typical form of $A$. Wrightii from central Durango strongly suggests $A$. brevipes Benth., from Aguascalientes, but differs from true $A$. brevipes, which has uniformly cordate leaves, and from the plants of San Luis Potosi, Hidalgo, and central Mexico with lobed leaves, which possibly are forms of it, in having more elongate flowers and in having the ovary at anthesis not covered with abundant soft slender more or less reflexed hairs but with less quickly evanescent rather rigid spreading ones. The stems of $A$. Wrightii have usually rather rigid spreading hairs; the stems of $A$. brevipes and immediately related forms have the hairs more or less retrorsely ascending or appressed. The range of $A$. Wrightii is to the north and west of the area occupied by $A$. brevipes.

I have seen typical $A$. Wrightii only from central Durango. The material of $A$. Wrightii from our area and adjoining United States differs from the typical Durango plant in being distinctly more robust, having larger flowers, and, most conspicuously, having an evidently tawny usually somewhat velvety indument of hairs that are longer, more slender, and more abundant. In 1940, on the basis of inadequate material, I attempted to distinguish the material of northern Chihuahua and Texas as var. texana. Subsequent collecting has shown that the extreme northern plants are indistinguishable from those found elsewhere in the area of the present report. The name 4. Wrightii var. texana, accordingly, can be amplified and redefined and used for all forms of $A$. Wrightii found in our area, thus permitting them to be distinguished from the typical form of $A$. Wrightii found in central Durango.

Plants representative of the amplified var. texana are known from northeastern Durango, eastern Chihuahua, and western Coahuila. Similar plants are known in eastern Coahuila only at Puerto San Lazaro and in the Sierra Gavia, about $75 \mathrm{~km}$. south of Monclova. In Texas the plant is known from Mesa Anguila and the Chinati, Vieja, Wyile, Eagle, and Davis Mountains. It has been recently collected in the Florida Mts., in Luna County, New Mexico (Ripley $\mathcal{E}$ Barneby 2486). In our area it is commonly found about the base of cliffs or in sheltered places at the base of rocky slopes. Occasionally, however, it occurs in silty soils in the shelter of bushes on flats subject to flooding after storms. In these latter conditions 
it becomes relatively luxuriant and develops leaves over $8 \mathrm{~cm}$. wide. The plant is highly esteemed as a medicinal herb, and in the areas where I have seen it, it is well-known under the name "Yerba del Indio." I have seen it for sale in the market at Chihuahua and have been told that it is also for sale at Torreon.

\section{POLYGONACEAE}

Eriogonum atrorubens Engelm. in Wislizenus, Mem. Tour. No. Mex. 108 (1848).

Coahuila: Carneros Pass area, July 1880, Palmer 1175.

Ranging in the mountains, pine and juniper belts, of Nuevo Leon and adjacent Coahuila, and in northern Durango and western Chihuahua north to extreme southwestern New Mexico. The type was collected near Cusihuiriachic, Chihuahua.

This and the following three species have dark-colored, purple or maroon flowers. The remaining species have pale yellow to whitish corollas frequently more or less stained with red or purple.

Eriogonum hemipterum Torr. ex Stokes, Gen. Eriogonum 21 (1936).

Eriogonum hieracifolium var. hemipterum Torr. \& Gray, Proc. Am. Acad. 8: 154 (1870).

Eriogonum hieracifolium f. atropurpureum Standl. Field Mus. Publ. Bot. 11:149 (1936) ; Mueller, Trans. Texas Acad. 20: 16 (1937).

Coahuila: Sierra del Carmen, Aug. 14, 1936, Marsh 660.

Known only from the Chisos Mts., Texas, and, to the southeast, in adjoining Coahuila, in the northern Sierra del Carmen. The type was collected by Parry on "Hillsides, along the cañons of the Rio Grande, above the mouth of the Pecos," probably near Boquillas Canyon.

Eriogonum hemipterum Torr. var. griseum var. nov.

A varietate typica differt foliis subtus dense et abundanter tomentosis.

Coahuila: Central parts of the Sierra del Pino, near the old log-slide, dry margins of pine forests, erect, 1-3 ft. tall, fl. maroon, 1940, Johnston $\mathcal{E}$ Muller 547 (TYPE, Gray Herb.) ; near Cañon Ybarra, central Sierra del Pino, dry slopes, fl. red, Stewart 1249; Sierra de los Pinos, Dec. 1937, LeSueur 1533. Chinuahua: Valley on high northwest end of Sierra Diablo, grassy meadow, not common, erect, fl. dark red, 1941, Stewart 968.

This plant, known only from the cited material, differs from typical E. hemipterum only in the very abundant grayish felt-like indument on the lower surfaces of its leaves and in the slightly more copious indument of more slender hairs on other parts of the plant.

Eriogonum rupestre Stokes, Gen. Eriogonum 21 (1936).

Vernacular name: Yerba colorado.

Chinuahua: Sierra Encinillas, $8 \mathrm{~km}$. east of Fierro, rocky hillside, not common, H. red, Stewart 760 .

The type and only other known collection of this species was obtained by Pringle (no. 285) on Sept. 28, 1885, in the hills northeast of Chihuahua. I have not seen authentic material, but Mr. Stewart's plant agrees well with the original description. The species is related to E. atrorubens, from which it differs only in its hairy perianth. It may be only a variety of that species ranging on the volcanic hills of eastern Chihuahua. 
Eriogonum ciliatum Torr. Bot. Mex. Bound. 175 (1859).

CoAhuila: Buena Vista, fl. dark purple, May 19, 1849, Gregg 83; mountains 6 mi. east of Saltillo, July 1880, Palmer 2088; San Lorenzo Canyon, southeast of Saltillo, scattered on grassy mesas, not common, fl. bright maroon, Sept. 1904, Palmer 385; Carneros Pass, Sept. 4, 1889, Pringle 2379; north end of Carneros Pass, 1-3 ft. tall, fl. brownish purple, Johnston $7287 ; 4 \mathrm{~km}$. east of Fraile, mountain-side, fl. purple, Stanford et al. 359 .

Ranging from southeastern Coahuila and northern Nuevo Leon south to northern San Luis Potosi and southern Tamaulipas. The original material of the species was collected on "sandy soil near Buena Vista" by Edwards and "near Monterey" by Gregg.

Eriogonum Greggii Torr. \& Gray, Proc. Am. Acad. 8: 187 (1870). Eriogonum ciliqtum var. foliosum Torr. Bot. Mex. Bound. 175 (1859).

Coahuila: Rancho Santa Teresa, south of Castaños, Wynd \& Mueller 181; Puerto San Lazaro, open grassy slopes, Muller 3073; Saltillo, stony hillside, May 1898, Palmer 166; Carneros Pass area, March 1880, Palmer 1176; high plain near San Juan de la Vaqueria, fl. purplish, May 20, 1847, Gregg 719 (TYPE); Sierra Pata Galana, March 1905, Purpus 1151.

Known elsewhere about Monterrey and near the Rio Grande in extreme southern Texas.

Eriogonum Abertianum Torr, in Emory, Notes Military Recon. 151 (1848).

Eriogonum pinetorum Greene, Muhl. 6:3 (1910).

Eriogonum Abertianum var. neomexicanum Gand. Compt. Rend. Soc. Bot. Belg. 42: 196 (1906).

Eriogonum Abertianum var. ruberrimum Gand. l. c.

Chinuahua: Near Lake Santa Maria, 1899, Nelson 6395.

This is a species ranging in northwestern Chihuahua (Casa Grandes, Col. Juarez, and Carretas), Sonora, Arizona, and western New Mexico. It is a slender erect plant, usually simple below but with forking cymosepaniculate branches above the middle. Its range approaches that of the more eastern and southern E. cyclosepalum, a species confused with it, only in northwestern Chihuahua and in the Rio Grande Valley near El Paso.

Eriogonum Abertianum var. villosum Fosb. Madroño 4: 191 (1938).

This plant has been collected near El Paso, Texas (Jones, Thurber). Doubtless it occurs in adjacent Chihuahua. The collection distributed by Gray as Wright 1762 is a mixture of typical E. cyclosepalum and E. Abertianum var. villosum and is composed of material collected by Charles Wright on March 21, 1852, in the Rio Grande Valley south of the Quitman Mts., and on April 19, 1852, on the "foothills towards Lake Santa Maria." Of this mixture I suspect that the latter Chihuahuan material is that representing E. Abertianum var. villosum.

I am unable to determine whether var. villosum is merely a vernal phase of E. Abertianum or perhaps even a distinct species. It has roughly the same distribution as E. Abertianum, but it appears to be a much coarser, more hairy, and more spreading plant with coarser more-flowered involucres and more elongate peduncles. It rarely shows the forking open branching of true E. Abertianum, and its leaves are thicker and never so strongly reduced up the stem. Var. villosum strongly suggests the vernal forms 
of E. cyclosepalum but is quickly distinguished by its very elongate peduncles, smaller paler flowers, and short involucre-lobes.

Eriogonum cyclosepalum Greene, Muhl. 6: 1 (1910).

Eriogonum lappulaceum Greene, Muhl. 6:2 (1910).

Eriogonum Abertianum subsp. lappulaceum Stokes, Gen. Eriogonum 37 (1936).

Eriogonum Abertianum var. cyclosepalum Fosb. Madroño 4: 192 (1938).

Eriogonum Abertianum var. lappulaceum Fosb. Madroño 4: 193 (1938).

Eriogonum Abertianum var. bracteatum Fosb. Madroño 4: 192 (1938).

Coahuila: Between Santo Domingo and Piedra Blanca, Wynd \& Mueller 495; Picachos Colorados, Johnston \& Muller 126; south base of Sierra Hechiceros, near El Tule, Stewart 538; Castillon, Stewart 386; near Santa Elena, Stewart 309; Cañon Tinaja Blanca, Sierra Cruces, Stewart 580, 2258; near Norias, 24 mi. north of Esmeralda, Johnston $\mathcal{E}$ Muller 333; valley west of Bufido, Johnston $\mathcal{E}$ Muller $845 a ; 3$ mi. west of San Antonio de los Alamos, Johnston \& Muller 860. Chinuahua: 5 mi. southeast of San Carlos, Johnston \& Muller 85; 4 km. south of Rancho Hechiceros, Stewart 213; road to Chihuahua, south of Carrizal, Aug. 21, 1846, Wislizenus 127; near Chihuahua, 1908, Palmer 25; plain near silver mill, Chihuahua, Aug. 4, 1885, Pringle 681; $11 \mathrm{mi}$. northeast of Camargo, Johnston 7891; 3 mi. west of Piloncillo, Johnston 7859.

Frequent in valleys and foothills, in silty or sandy soils. Growing among grass, under bushes, or in bare open places. The plant ranges from transPecos Texas south through Coahuila and eastern Chihuahua to San Luis Potosi. In the past it has been confused with the more northerly and western $E$. Abertianum, but it may be readily distinguished by its more compact lower growth-habit, its strict usually rather numerous stems bearing racemosely disposed involucres, its elongate involucre-lobes, and its slightly larger yellow or yellowish more or less conspicuously red-tinged perianth-lobes.

In his recent study of this group Fosberg treated our plants as varieties of E. Abertianum, referring the vernal forms to var. cyclosepalum and the summer phases to var. bracteatum. I do not believe such seasonal forms merit nomenclatorial recognition. Fosberg's E. Abertianum var. Gillespiei is a plant of Maricopa and Pinal Counties, Arizona, which appears to be an outlying isolated population related much more closely to E. cyclosepalum than to E. Abertianum and which I believe should be called E. cyclosepalum var. Gillespiei (Fosb.) comb. nov.

Eriogonum annuum Nutt. Trans. Am. Philos. Soc. 5: 164 (1837).

Chinuahua: Dunes south of Salamayuca, Sept. 20, 1886, Pringle 798; Los Medanos, 1935, LeSueur 414; near Carrizal, sandhills, Aug. 18, 1846, Wislizenus 104; sandhills near Cantarrecio, Oct. 1852, Thurber 819.

A plant of sandy soils, ranging from northern Chihuahua north to the central United States.

Eriogonum polycladon Benth. in DC. Prodr. 14: 16 (1856).

Chinuahua: $5 \mathrm{~km}$. north of Escobillas, rocky slopes, frequent, fl. reddish, Stewart 2373; Chihuahua, ex herb. Scheer [Potts].

Arizona to trans-Pecos Texas (Davis Mts.) and south into Chihuahua and Sonora. The species has been collected repeatedly in the highlands of western Chihuahua and northern Sonora. Pringle is listed as having collected the species near Chihuahua (no. 644). Potts' material may have come from near Chihuahua City or from the mountains to the west. Mr. 
Stewart's collection comes from the extreme northeastern part of the state.

Eriogonum rotundifolium Benth. in DC. Prodr. 14: 21 (1856).

Vernacular name: Chuchaca.

CoAhuila: $10 \mathrm{~km}$. west of San Guillermo, tobosa flat, fl. white, Stewart 1762; $9 \mathrm{~km}$. south of El Tule, south base of Sierra Hechiceros, dry hillside, fl. white, Stewart 451; Picacho Noche Buena, lava-strewn slope, Johnston \& Muller 166; Castillon, silty arroyo at margin of gypsum flat, Johnston $\mathcal{E}$ Muller 1274; south of Laguna Leche, silty flat in somewhat saline and gypseous soil, Johnston 8623; near La Rosa, northwest of Saltillo, Shreve \& Tinkham 9906. Chinuahua: 3 mi. south of Providencia, silty slope, Johnston \& Muller 108; 11 mi. west of Providencia, silty desert plain, Johnston \& Muller 104; Rancho El Pino, about $10 \mathrm{~km}$. southeast of Sierra Rica, dry sandy flat, fl. white, Stewart 2560; dry hills and mesas near Juarez, May 5, 1901 and Sept. 26, 1902, Pringle 9444, 11155.

An associate of Larrea on valley slopes and one showing a preference for silty, frequently somewhat gypseous soils. From our area ranging north into Arizona, New Mexico, and trans-Pecos Texas.

Eriogonum Wrightii Benth. in DC. Prodr. 14: 15 (1856).

Coahuila: Sierra del Carmen, Sept. 7, 1936, Marsh 806; Puerto Colorado, crevices in sandstone, globose bush 12-18 inches tall, Johnston 8696; Sierra Hechiceros, Cañon Indio Felipe, creek-banks, Stewart 110; northern foothills of Sierra Cruces, gravelly open arroyo, bush $1 \mathrm{ft}$. tall, 2-3 ft. broad, fl. white, Johnston \& Muller 1053; Cañon Tinaja Blanca, Sierra Cruces, sunny open slopes in upper canyon, erect, shrubby, 1-2 ft. tall, Johnston \& Muller 295. Chinuahua: $8 \mathrm{~km}$. south of Rancho Hechiceros, in arroyo, fl. white, Stewart 216; along Sierra Seca, 20 km. north of Rancho San José del Progreso, rocky slopes, fl. white, Stewart 2350; $3 \mathrm{mi}$. north of Mesteñas, dry rocky slope in canyon, Johnston 7950; low ridge a mile southwest of Mesteñas, rocky slope, fl. white, Stewart $\mathcal{E}$ Johnston 2031. ZaCatecas: Concepcion del Oro, 1902, Palmer 381.

Ranging from San Luis Potosi and Zacatecas northward and northwestward into trans-Pecos Texas, New Mexico, and Arizona. The type came from extreme western Pecos County, Texas. The plant usually grows in gravelly or rocky soils and forms an erect bushy mass a foot or more tall.

Eriogonum tenellum Torr. Ann. N. Y. Lyceum 2: 241 (1827).

Eriogonum tenellum var. leptocladon Benth. in DC. Prodr. 14: 20 (1856).

Vernacular names: Chuchaca; Chacate.

Coahuila: Sierra del Carmen, Cañon Sentenela, Wynd \& Mueller 615; Piedra Blanca, igneous hills, Wynd \& Mueller 499; Parras, 1880, Palmer 1173; Cañon Indio Felipe, Sierra Hechiceros, sides of arroyo, Stewart 159; Sierra Cruces, Cañon Tinaja Blanca, rocky side of narrow canyon, Johnston \& Muller 267; near Santa Elena, rocky hillside, fl. white, Stewart 570; San Antonio de los Alamos, crevices in volcanic tuff, Johnston \& Muller 891. Chinuahua: 14 mi. west of San Carlos, gravelly bed of arroyo, Johnston \& Muller 29; $4 \mathrm{~km}$. north of Rancho El Pino, southeast of Sierra Rica, rocky slope, fl. white, Stewart 2424; Sierra Virulento, rocky bench at base of sierra, Johnston 8086; Sierra Encinillas, near Fierro, rocky hillside, fl. white, Stewart 766; Los Organos, local on rocky flat, fl. white, Stewart \& Johnston 2056; Los Organos, 1937, LeSueur 1310; rocky hills west of Chihuahua, April 24, 1885, Pringle 169; Chihuahua, stony mesas, fl. white, 1908, Palmer 80.

Ranging from our area northward through trans-Pecos Texas to western Oklahoma and thence westward in northern New Mexico and southern Colorado. A plant of well-drained, usually rocky or gravelly soil in exposed situations, with a rather compact multicipital caudex, basal clusters of petiolate ovate to broadly orbicular white-tomentose leaves, and naked flowering branches. 
Eriogonum tenellum Torr. var. ramosissimum Benth. in DC. Prodr. 14: 20 (1856).

Chinuahua: Sierra de los Organos, Sept. 1937, LeSueur 2006.

This variety has been previously known only from the igneous area of central Texas (Llano and Gillespie Counties), east of the area from which typical E. tenellum is known. From typical E. tenellum it differs in having a very much looser caudex with the small acutish ovate leaves scattered along the lower $5-15 \mathrm{~cm}$. of the flowering stem. Its low usually sprawling slender growth-habit, small acutish leaves, and smaller flowers quickly distinguish it from E. platyphyllum. Although from far to the southwest of previously known stations of var. ramosissimum, LeSueur's collection from the Sierra Organos seems indistinguishable from it, as well as conspicuously different from the material of typical E. tenellum which has been collected in the same sierras. The variety may deserve specific rank.

Eriogonum platyphyllum Torr. ex Benth. in DC. Prodr. 14: 20 (1856).

Eriogonum tenellum var. platyphyllum Torr. Bot. Mex. Bound. 176 (1859).

Coahuila: Rancho Agua Dulce, shrub-covered valley floor, 1936, Wynd \& Mueller 412; Rancho Babia, 1938, Marsh 1208; Santa Anna Canyon, July 15, 1936, Marsh 489; Soledad, Sept. 1880, Palmer 1174; Sierra Guajes, Cañon Milagro, in arroyo, fl. yellowish white, Stewart 1537; several miles below Palos Blancos, road between Ocampo and Cuesta Zozaya, gravelly bench on open canyon-floor, Johnston 9264.

Ranging from our area north into the Big Bend and along the south escarpments of the Edwards Plateau (mouth of Terlingua Creek, Havard 114; southwest of Langtry, Cory 19414; 10 mi. west of Laguna, Kinney Co., Cory 29317; and Nueces River west of Uvalde, Wright 618, type). Although obviously related to E. tenellum, its elongate erect shrubby very leafy stems and larger flowers readily distinguish it from that more westerly ranging species.

Eriogonum Jamesii Benth. in DC. Prodr. 14: 7 (1856).

Eriogonum undulatum Benth. in DC. Prodr. 14: 7 (1856).

Coahuila: Sierra del Carmen, Cañon Sentenela, Wynd $\mathcal{E}$ Mueller 616; Sierra del Carmen, Aug. 9, 1936, Marsh 688; Mesa Grande, northwest of Hac. Encantada, fl. whitish, Stewart 1650; crest of Sierra Encantada, fl. reddish, Stewart 1460; betw. south end of Hillcoat Mesa and Buena Vista headquarters, July 27, 1938, Marsh 1495; Sierra Gloria, 1939, Marsh 1918; Lerios, July 1880, Palmer 1172; 3 km. southwest of Fraile, in arroyo, fl. white, Stanford et al. 335; Sierra del Pino, rocky places along high arid crest, Johnston $\mathcal{E}$ Muller 554; western escarpment of Potrero de la Mula, sunny ridge below crest, Johnston 9242; Sierra Madera, Cañon Pajarito, dry arroyo banks, fl. greenish white tinged with red, Muller 3186; Sierra Madera, Cañon Charretera, opening in oak-chaparral, rocky canyon floor, Johnston 9004; Sierra Hechiceros, Cañon Indio Felipe, crevices of cliffs, Stewart 82; Sierra Hechiceros, Cañon Madera, sunny ledges on cliffs, Johnston $\mathcal{E}$ Muller 1296; Picacho Noche Buena, lava cliffs, Johnston \& Muller 181; Sierra Cruces, near Santa Elena, sandy arroyo, fl. white, Stewart 311; highest peaks of Sierra Cruces, rocky slopes, Stewart 1143; San Antonio de los Alamos, crevices about summit of tuff cliffs, Johnston $\mathcal{E}$ Muller 951; Sierra Parras, July 1910, Purpus 4606; Sierras Negras, $9 \mathrm{~km}$. south of Parras, fl. white, Stanford et al. 162; Picacho de Jimulco, summit, Stanford et al. 95. Chruuahua: Cañon Madera, Sierra Rica, rocky arroyo and sunny slopes, fl. white, Stewart 2489, 2541; Los Organos, 1937, LeSueur 1309; Cerro Coronel, Chihuahua, Aug. 5, 1885, Pringle 680. Zacatecas: Mountains $18 \mathrm{~km}$. west of Concepcion del Oro, fl. white, Stanford et al. 568 . 
Ranging from Hidalgo along the eastern Sierra Madre into our area and from thence northward to Kansas, Colorado, and Arizona. Growing in well-drained places, along arroyos, in openings in oak-chaparral, and on exposed ledges and cliffs, and varying in habit accordingly. In sheltered places it becomes $3-5 \mathrm{dm}$. tall and has large leaves frequently grayish with a thin indument on the upper surface. On exposed ledges and about cliffs it is commonly only $1-2 \mathrm{dm}$. tall and usually has a well-developed trailing woody caudex with russet shreddy bark and crowded small leaves quickly glabrous and bright green above. The various forms of this widely ranging species vary greatly in appearance but the variants are not geographically correlated and seem best dismissed as ecological forms.

Rumex hymenosepalus Torr. Bot. Mex. Bound. 177 (1859).

Vernacular name: Lengua de Vaca.

Chinuahua: Near Chihuahua, rich moist soil on river bank, 1908, Palmer 27.

Ranging from California east to southwestern Wyoming and western Texas, and south into northern Mexico. The species was originally based upon two specimens, Thurber 140, from Hueco Tanks northeast of El Paso, and Wright 1782, from the western side of the Rio Grande in Dona Ana County, New Mexico, a short distance north of the international boundary.

Rumex altissimus Wood, Class Book ed. 2.477 (1847).

Chinuahua: Near Chihuahua, by stream, May 28, 1888, Pringle 5540.

Ranging in the eastern United States west to the base of the Rockies and south through Texas, New Mexico, and Arizona into northern Mexico.

Rumex mexicanus Meisn. in DC. Prodr. 14: 45 (1856).

Coahuila: Fraile, common in valley, Stanford et al. $275 ; 3 \mathrm{~km}$. southwest of Fraile, in arroyo, Stanford et al. 329. Chinuahua: Presa de Chihuahua, 1936, LeSueur 608.

Widely distributed in the United States, south through Arizona and New Mexico, and along the Sierra Madre Occidental into central Mexico. I am unable to distinguish Mexican material from northern plants segregated recently as $R$. triangulivalvis (Dans.) Rech. The Coahuilan specimens cited above are in flower and lack fruit. They may possibly represent $R$. Berlandieri Meisn. of eastern Texas and eastern Mexico.

Rumex violascens Rech. Repert. Sp. Nov. 39:171 (1936), Field Mus. Publ. Bot. 17: 131. f. 23 (1937).

Coahuila: Don Martin Dam, White 1376; San Lorenzo de la Laguna, 1880, Palmer 1182.

Valley of the Rio Grande along our northern limits west, in southern New Mexico and Arizona, into California, and south in Coahuila. The species was described from a large and representative suite of specimens, but no type was designated.

Rumex crispus L. Sp. Pl. 335 (1753).

Vernacular name: Lengua de Vaca.

Coahuilla: Monclova, Marsh 1678; Saltillo, Feb. 20, 1847, Gregg; Parras, 1880, Palmer 1181. Chinuahua: Presa de Chihuahua, LeSueur 605; Chihuahua, common along river and ditches and in low ground, 1908, Palmer 97, 223. 
A European plant widely established in wet soils in America. It has been repeatedly collected in the Rio Grande Valley below El Paso.

Polygonum coccineum Muhl. ex Willd. Enum. Pl. 1: 428 (1809).

Chinuahua: 3 miles west of Camargo, fl. pink, White 2269.

Widely distributed in the United States and ranging south to Central America. The cited collection represents the forma terrestre Stanford, Rhodora 27: 169 (1925).

Polygonum lapathifolium L. Sp. Pl. 360 (1753).

Coahuilla: Sierra del Carmen, Sept. 8, 1936, Marsh 761; Sabinas River near Muzquiz, Marsh 402. Chinuahua: Near Chihuahua, moist shady place along river, 1908, Palmer 332.

Widely distributed in America; apparently introduced from Europe. It appears to be generally distributed along the Rio Grande at our northern limit.

Polygonum persicarioides H.B.K. Nov. Gen. et Sp. 2: 179 (1818).

Polygonum hydropiperoides Michx. var. persicarioides Stanford, Rhodora 28:27 (1926).

Coahulla: Monclova, Marsh 1681; Monclova, edge of river, White 1769; Cañon Indio Felipe, Sierra Hechiceros, bank of creek, Stewart 95; south base of Sierra Hechiceros, mud at Tanque La Palma, Johnston $\mathcal{E}$ Muller 1282.

Ranging from southern California to Texas and south through Mexico to South America. The species has been collected in the Rio Grande Valley in the Big Bend.

Polygonum pensylvanicum L. Sp. Pl. 362 (1753).

Chinuahua: Pond just east of Organos, growing in standing water, Stewart $\mathcal{E}$ Johnston 2049.

Widely distributed in eastern United States and south in Mexico.

Polygonum punctatum Elliot, Bot. S. Car. and Georgia 1: 455 (1817).

Coahulla: Muzquiz Swamp, Sept. 15, 1936, Marsh 931. Chinuahua: Rio Concho at Camargo, White 2245.

Widely distributed in America.

Polygonum aviculare L. Sp. Pl. 362 (1753).

Coahulla: Saltillo, in river bottom, rare, 1898, Palmer 570. Chinuahua: Vicinity of Chihuahua, low moist river bottom, prostrate, 1908, Palmer 185.

Widely distributed in America as a weed along roads and in gardens.

Polygonum ramosissimum Michx. Fl. Bor. Am. 1: 237 (1803).

Collected in the bottom-lands along the Rio Grande in El Paso (Wright 1775 ) and Hudspeth (Waterfall 3968 and 4598) Counties and hence, doubtless, occurring in adjacent Chihuahua. Widely distributed in the United States.

\section{CHENOPODIACEAE}

Chenopodium ambrosioides L. Sp. Pl. 219 (1753).

Vernacular names: Hipazote; Istafiate.

Coahuila: Sierra del Carmen, Aug. 9, 1936, Marsh 681; Rancho Babia, Marsh 1213; La Azufrosa, 3 ft. tall, scarce, 1848, Gregg 515; Parras, 1898, Palmer 445; San Lorenzo de la Laguna, 1880, Palmer 1153. 
Widely distributed in America as a weed and a medicinal herb.

Chenopodium dissectum (Moq.) Standl. No. Am. Fl. 21: 26 (1916).

Coahuila: Saltillo, low places and on top of a stony mountain, odor strong, 1898, Palmer 353 .

Ranging from Coahuila south to central Mexico.

Chenopodium graveolens Lag. \& Rodr. Anal. Cien. Nat. 5: 70 (1802).

Chenopodium incisum Poir. in Lam. Encyc. Suppl. 1: 392 (1811).

Vernacular names: Yerba del Zorillo; Colo de Zorillo.

CoAhuila: San Antonio de las Alanzanas, 1-2 ft. tall, scarce, Aug. 31, 1848, Gregg 390; Carneros Pass area, Aug. 1880, Palmer 1150. Chinuahua: Cañon Madera, Sierra Rica, open sunny slopes, Stewart 2459, 2502; canyon west of Organos, along arroyo and under liveoaks, Stewart \& Johnston 2077; Sierra Santa Eulalia, Oct. 9, 1885 , Pringle 552.

A native species ranging from trans-Pecos Texas to Arizona and south to Central America. It is sold as a medicinal plant in the market at Chihuahua.

Chenopodium murale L. Sp. Pl. 219 (1753).

Coahuila: Monclova, 1939, Marsh 1728, 1842.

A European weed widely established in America. It has been collected in the bottoms of the Rio Grande near Boquillas, Texas.

Chenopodium Fremontii Wats. Bot. King's Exped. 287 (1871).

Coahuila: Cañon Indio Felipe, Sierra Hechiceros, abundant at base of talus-slope, Stewart 40; Cañon Indio Felipe, dry sandy arroyo, Stewart 58; north base of Sierra Cruces, dry open bed of arroyo, Johnston \& Muller 1051; Tinaja Blanca, Sierra Cruces, sandy arroyo, not common, Stewart 317; Carneros Pass, shaded ravines, Sept. 11, 1889, Pringle 2308. Chinuahua: Rio Grande, Oct. 1852, Thurber 817.

Widely distributed in the western United States and south into northern Mexico. Among the collections cited Stewart 40, Pringle 2308, and Thurber 817 are very similar and clearly conspecific. They represent the loosely branched slender-stemmed plant with thin, green, practically glabrous leaves. Aellen, in Repert. Sp. Nov. 26: 141 (1929), cites Pringle 2308 and the very similar Wright 570 (from the Rio Grande bottoms below El Paso) as C. Fremontii. The other collections which I have cited are much less mature, less branched, somewhat farinose, and lack mature fruit. Their difference may be caused by their immaturity. They may, possibly, be forms transitional to $C$. incanum.

In my identifications of this and the following four species I have tried to follow Aellen, using his "Beitrag zur Systematik der Chenopodium-Arten Amerikas," in Repert. Sp. Nov. 26: 31-64, 119-160 (1929), and the "Key and Synopsis of the American Species of Chenopodium" by Aellen \& Just, in Am. Midl. Nat. 30:47-76 (1943). The material from the area is scanty and much of it without mature fruits, and very many specimens must be collected and studied before our species can be satisfactorily identified, if, indeed, that will ever be possible in this complex genus.

Chenopodium incanum (Wats.) Heller, Pl. World 1: 23 (1897).

Chrmuahua: Vicinity of Chihuahua, old fields and waste places, 1908, Palmer 342.

According to Aellen, Repert. Sp. Nov. 26: 144 (1929), the species 
ranges in the western United States and south to Zacatecas. He cites the collection of Palmer listed above, as well as a collection of Mearns from White Water on the international boundary in northwestern Chihuahua.

Chenopodium arizonicum Standl. No. Am. Fl. 21: 19 (1916).

Coahuila: San José, southeast base of Sierra Cruces, basalt hill, rocky slope, Johnston \& Muller 982a; San Antonio de los Alamos, flats on summit of tuff cliffs, Johnston 8260; Parras, 1880, Palmer 1151.

Aellen, Repert. Sp. Nov. 26: 120 (1929), cites material of this species from Utah, Arizona, and northern Mexico. He cites Palmer 310 (1902), from Saltillo, and Palmer 1151, which I have cited above. The other collections from Coahuila which I have listed are similar to Palmer 1151. The plant suggests a xerophytic form of $C$. incanum with small scarcely angular leaves.

Chenopodium pratericola Rydb. Bull. Torr. Bot. Cl. 39:310 (1912) ; Aellen, Ostenia 99 (1933).

Chenopodium petiolare var. leptophylloides Murr, Bull. Herb. Boiss. II. 4: 994 (1904).

Chinuahua: Near Ortiz, May 26, 1888, Pringle 1992 (isotype of $C$. petiolare var. leptophylloides).

Widely distributed in the western United States according to Aellen, Repert. Sp. Nov. 23: 134 (1929).

Chenopodium leptophyllum Nutt. ex Wats. Proc. Am. Acad. 9:94 (1874); Aellen, Ostenia 99 (1933).

Chenopodium inamoenum Standl. No. Am. Fl. 21: 15 (1916), Bull. Torr. Bot. Cl. $44: 413$ (1917).

The type of $C$. inamoenum, which Aellen identifies with the true $C$. leptophyllum, was collected by Mearns near White Water, near the international boundary, in northwestern Chihuahua. Similar plants have been collected in the bottom-lands of the Rio Grande below El Paso.

Meiomeria stellata (Wats.) Standl. No. Am. Fl. 21: 7 (1916).

Chenopodium stellatum Wats. Proc. Am. Acad. 18: 146 (1883).

Coahuila: Mountains $21 \mathrm{mi}$. northeast by north of Monclova, Sept. 1880, Palmer 1155 (TYPE); saline soil on flats $4 \mathrm{mi}$. west of Cuatro Cienegas, Johnston 7134; saline gypsum flat on slope east of Lag. Jaco, Stewart $\mathcal{E}$ Johnston 1956.

An endemic genus known only from the collections cited. It is a small erect annual herb $1-10 \mathrm{~cm}$. tall, extremely succulent, and abundantly floriferous from the base upward. The plant is simple or, more commonly, with few to many ascending or rarely somewhat decumbent branches from the base. At the two localities where I have seen this plant it grew most abundantly on Upper Cretaceous beds along the contact of gypsum and saline clays. It appears to be a halophytic gypsophile. From the distance and directions given on Palmer's label (data frequently very inaccurate), the type may have been collected near Hermanas, an area where this plant can very well be expected.

Cycloloma atriplicifolium (Spreng.) Coulter, Mem. Torr. Bot. Cl. 5: 143 (1894).

Chinuahua: Los Medanos, Oct. 1935, LeSueur 383.

Sandy places in the middle United States south to Arizona and Texas and 
into adjoining Mexico. The plant has been collected on the Texan side of the Rio Grande at Santa Helena Canyon.

Atriplex canescens (Pursh) Nutt. Gen. Pl. 1: 197 (1818).

Vernacular names: Costilla de Vaca; Saladillo; Chamizo; Cenizo; Huele de Noche.

Coahulla: Rio Grande Valley near Piedras Negras, April 24, 1900, Pringle 8298; vicinity of Encantada Ranch and eastward to the escarpment, July 30, 1938, Marsh 2263; west slopes of Sierra del Carmen northeast of Hac. Encantada, arroyo-bank, shrub $15 \mathrm{dm}$. tall, Stewart 1557; Valle de los Guajes, common on grassy flat, shrub $15 \mathrm{dm}$. tall, Stewart 1326; valley near Flores, north of Cuatro Cienegas, in mesquite forest, rare, Johnston 8876; Cuatro Cienegas, Marsh 2025, 2051, 2067; salt-lands $3 \mathrm{mi}$. south of Cuatro Cienegas, shrub $2 \mathrm{~m}$. tall, White 1918; valley near Mesillas, 2-5 ft., abundant, Gregg 522; Saltillo, three plants only, 21/2 ft. tall, Sept. 1898, Palmer 298, 303; south of Fraile, shrub 3-6 ft., slopes, Johnston 7319; La Ventura, Nelson 3905, 3924; Cañon Ybarra, Sierra del Pino, arroyo-banks, Stewart 1915; east base of Sierra Cruces, $10 \mathrm{~km}$. north of Santa Elena, shrub 10-15 dm. tall, fairly common, Stewart $395 ; 15 \mathrm{~km}$. south of Puerto de San José, rocky hillside, 1-2 m. tall, Stewart 842; northwestern end of Sierra Planchada, common on tobosa-flat, shrub $15 \mathrm{dm}$. tall, Stewart 1015; Laguna de Leche, shrub 2 ft. tall, Muller 3286; Noria de San Juan, southeast of Laguna Rey, saline flat, $1 \mathrm{~m}$. tall, Stewart 3007; $30 \mathrm{mi}$. south of Sierra Mojada, Wynd 762, 772; Parras, June 1880, Palmer 1163; plains east of Parras, April 11, 1847, Gregg; San Lorenzo de la Laguna, May 1880, Palmer. Chinuahua: South end of Sierra Seca, $5 \mathrm{~km}$. south of Rancho San José del Progreso, shrub $1 \mathrm{~m}$. tall, Stewart 2308; near Lake Santa Maria, shrub 2-3 ft. tall, Nelson 6410; north of the Sand Dunes, LeSueur 282; road to Camargo, $33 \mathrm{mi}$. north of Jimenez, shrub $15 \mathrm{dm}$., White 2183; 9 mi. north of Escalon, shrub $1 \mathrm{~m}$. tall, White 2071. Durango: Andabazo Creek, May 7, 1847, Gregg; plains near Pasaje, Shreve 9121. Zacatecas: Cedros, near cultivated ground, Kirkwood 37, 39, 50.

A widely distributed shrub in the western United States; in all parts of trans-Pecos Texas, but in central Texas extending south to the escarpments of the Edwards Plateau. Ranging south through our area to San Luis Potosi. I have seen no material from Tamaulipas or Nuevo Leon. An unobtrusive but widely distributed shrub in Coahuila. It is most common in silty soils, particularly about mogotes, on valley slopes, but it is also frequent along arroyo banks in the lower canyons. In the volcanic grassy areas of eastern Chihuahua it is much less common.

Atriplex prosopidum Johnston, Jour. Arnold Arb. 24: 227 (1943).

Coahuila: $10 \mathrm{mi}$. north of Cuatro Cienegas, Wynd 742, 744; south of El Oso, rounded bush 2-3 ft. tall, Johnston 8877 (TYPE) ; near Flores, globose bush 1-4 ft. tall, abundant, with Suaeda, in mesquite forest, Johnston $8875 ; 12 \mathrm{mi}$. north of Monclova, bush 3-4 ft. tall, mesquite-covered valley floor, Johnston 7187 .

Known only from the collections cited above. A plant of silty, somewhat saline and gypseous valley soils. Growing with Prosopis glandulosa and usually in company with Suaeda. A relative of A. canescens, from which it differs in selection of habitat, indument, form of growth, color of herbage, shape of leaves, and size and shape of fruiting bracts.

Atriplex obovata Moq. Chenop. Enum. 61 (1840).

Atriplex Greggii Wats. Proc. Am. Acad. 9: 118 (1874).

Coahuila: Perros Bravos, $1 \mathrm{ft}$. tall, abundant, Sept. 20, 1848, Gregg 462 (type of A. Greggii) ; valley $8 \mathrm{mi}$. north of Avalos, saline flats, common, shrub 6-15 inches tall, Johnston 7341; $12 \mathrm{mi}$. north of La Ventura, local, alkaline flat, shrub 12-18 in. tall, Johnston 7649; Llano de Guaje, flats near Tanque La India, common, erect globose 
bush 6-18 in. tall, Johnston \& Muller 779; valley floor 3-4 mi. east of Puerto Caballo, frequent, Johnston 8318; Laguna de Leche, flats about lake, globose bush 1-21/2 ft. tall, Johnston 8598; bottom of large valley southeast of Zacatosa, frequent, erect globose bush 10-18 inches tall, Johnston 8645 ; bottom of valley between La Vibora and Matrimonio, common, globose bush 6-24 inches tall, Johnston 9331; 2 mi. west of San Vicente, saline gypseous slopes east of Laguna de Jaco, bush 2-4 dm. tall, fairly common, Stewart $\mathcal{E}$ Johnston 1967; saline flats at southeastern end of Laguna de Jaco, common bush, globose, up to 16 inches tall, Johnston \& Muller 1083, 1084, 1086. Chinuahua: Barreal, north of Jaco, saline flats, 2-3 dm. tall, Stewart 669 ; north of Sand Dunes, 1935, LeSueur 281. Zacatecas: Cedros, Lloyd 83, 132. Durango: $3 \mathrm{mi}$. northeast of Bermejillo, somewhat saline soil on flats, shrub 6-30 inches tall, Johnston 7784. SAN Luis Potosi: 2 mi. northwest of Cedral, saline flats, 6-12 inches tall, Johnston 7598, 7599; San Vicente, Shreve 9351; Hacienda del Salada, about 55 km. north-northwest of Cedral, Dec. 24-25, 1827, Berlandier 1346 (ISOTYPE).

Ranging from northern San Luis Potosi north through Coahuila and eastern Chihuahua to the valley of the Rio Grande. The type was collected in extreme northern San Luis Potosi. I have listed all the collections of this species which I have seen from Mexico. In Texas the plant has been collected on Tornillo Creek, Chisos Area (Havard 103), and near old Fort Quitman (Cory 31039). The plant from the vicinity of El Paso and west to southeastern Arizona, usually referred to A. obovata, is a greener more slender plant and at least varietally distinct from our Mexican species.

This species grows on evidently saline and gypseous soils, in the company of marked halophytes such as Suaeda and Allenrolfea, and also on the periodically flooded and desiccated flats on valley-bottoms, where marked halophytes and surface signs of high gypsum and salt contents are absent. In Coahuila $A$. obovata frequently associates with either $A$. acanthocarpa or A. Stewartii. It is usually a small rounded bush $2-5 \mathrm{dm}$. tall. Rarely it reaches a meter in height.

Atriplex acanthocarpa (Torr.) Wats. Proc. Am. Acad. 9: 117 (1894).

Vernacular Name: Quelito.

Coahuila: Perros Bravos, 3 ft. tall, abundant, Sept. 20, 1848, Gregg 459; valley $8 \mathrm{mi}$. north of Avalos, saline flats, slender shrub 1-3 ft. tall, common, Johnston 7334, 7335,7342 ; silty plain $20 \mathrm{mi}$. west of Saltillo, common, decumbent or sprawling, 6-30 inches high, Johnston 7666; desert $48 \mathrm{mi}$. west of Saltillo, saline flats, decumbent, 6-24 inches high, common, Johnston 7695; 5 mi. north of Parras, saline flat, Johnston 7702; San Lorenzo de la Laguna, May 1880, Palmer 473; near Horizonte, Wynd 773; Torreon, alkaline areas on plains, about $2 \mathrm{ft}$. tall, 1898, Palmer 473; Bolson de Mapimi [near the Nazas between San Sebastian and San Lorenzo], dry valleys, common, May 11, 1847, Gregg; 5 mi. west of Viesca, moderately saline slope, decumbent or clambering, Johnston 7738. Chinuahua: Lake Santa Maria, Nelson 6409; 8-14 mi. south of Ojinaga, saline and gypseous flats, globose bush $1-3 \mathrm{ft}$. tall, common, Johnston $\mathcal{E}^{\circ}$ Muller 1447.

A plant becoming 1-3 ft. tall with usually sprawling or loosely decumbent stems. Frequently clambering in bushes. Usually associated with $A$. obovata and commonly frequenting obviously saline as well as gypseous soils. Frequently associated with Suaeda. Included in the species are a group of more or less geographical races which have not been named. These range in southeastern Arizona, southern New Mexico, along the Rio Grande Valley in trans-Pecos Texas, and southern Texas, and thence south into Tamaulipas and through our area into northern Zacatecas and 
northeastern Durango. Atriplex Pringlei Standl., of northern and eastern San Luis Potosi, is the southernmost member of this complex. The typical forms of A. acanthocarpa, growing in the valley of the Rio Grande above the Big Bend, are more shrubby and apparently more erect and have firmer broader less lobed paler leaves than the plant of southern Coahuila. The plant of southern Texas has very slender stems and narrower, thinner, greener, nearly entire leaves. In the middle western parts of Coahuila $A$. acanthocarpa appears to be replaced by the closely related $A$. Stewartii. The northern limit of $A$. acanthocarpa has not been established in Durango and southern Coahuila. The species will doubtless be found in the saline valleys of northeastern Chihuahua north of the Conchos, when that area is explored.

Atriplex Stewartii Johnston, Jour. Arnold Arb. 22: 110 (1941).

Coahuila: Llano de Guaje near Tanque La India, common about margin of flats, erect bush up to 18 inches tall, Johnston \& Muller 781; Llano de Guaje, near Tanque La India, growing among low bushes and partially supported by them, stems $3 \mathrm{ft}$. long, Johnston \& Muller 785; Llano de Guaje, edge of flats $10 \mathrm{~km}$. east of Tanque La India, erect bush, common, Stewart 1174, 1175; margin of Llano de Guaje at base of Lomas del Aparejo about 3 mi. south of Tanque Aparejo, abundant, erect, 10-16 inches tall, Johnston \& Muller 777 (TYPE); Laguna de Leche, flats about lake, 1-3 ft. tall, frequent, much browsed, Johnston 8592, 8594; near Tanque La Palma, several miles south of Laguna Leche, common on silty flats, 6-12 inches tall, Johnston 9331; bottom of large valley southeast of Zacatosa, common on silty flats, Johnston 8646, 8647, 8648; silty flats in valley between La Vibora and Matrimonio, erect or somewhat sprawling, 6-12 inches tall, Johnston 9332; flats west of Americanos, common, Johnston 9387A-D.

Endemic to our area. A plant of heavy silty valley soils subject to periodic floodings and droughts, and usually associated with $A$. obovata. I have not observed the plant in the company of marked halophytes, such as Suaeda, nor in soils that are evidently saline. It is frequently erect but commonly is decumbent or sprawling or scrambling in low bushes, and is rarely more than 3-4 dm. tall. It is usually much more browsed than its companion species, A. obovata.

The plant has the growth-habit and vegetative characters of $A$. acanthocarpa, but differs from that related species in having the fruit regularly 4-winged rather than covered with irregularly arranged appendages. It replaces $A$. acanthocarpa in western middle Coahuila. How the species behaves as it approaches the area in which $A$. acanthocarpa grows is unknown. Unfortunately I have no good fruiting material of these plants from such strategic areas as Cuatro Cienegas, Laguna del Rey, Laguna Palomas, Valle Acatita, or Valle de las Delicias. I have one fruiting specimen from the saline flats 4 miles west of Cuatro Cienegas (Johnston 7136), which possibly may be referable to $A$. Stewartii, though this seems doubtful. The habitat near Cuatro Cienegas is very saline and more in accord with the known soil preference of $A$. acanthocarpa.

Atriplex reptans Johnston, Jour. Arnold Arb. 22:111 (1941).

Coafuila: Saline gypseous flat east of Laguna del Jaco, locally abundant, Johnston $\mathcal{E}$ Muller 1080, 1081 (TYPE), Stewart E Johnston 1975. SAN Luis Potosi: Santo Domingo, 1934, Lundell 5584. 
A species known only from the two localities cited above. A creeping perennial with very small crowded opposite leaves. At the type locality, on the slope east of Lake Jaco, 3 miles west of San Vicente, the plant is locally abundant on a gypsum flat which catches the drainage flowing down the slope over extensive exposures of saline and gypseous clays.

Atriplex monilifera Wats. Proc. Am. Acad. 9: 111 (1874).

Endolepis monilifera Standl. No. Am. Fl. 21: 73 (1916).

VernacUlar NAME: Quelito.

CоAнuila: Dried up lake-bed in Bolson de Mapimi, April 13, 1847, Gregg (TyPe); Laguna de Viesca, alkaline soil about lake-bed, Johnston 7732.

A very distinct endemic annual species. The type was collected about the south margin of Laguna de Mayran.

Atriplex abata Johnston, Jour. Arnold Arb. 21 : 67 (1940).

COAHuila: 11 miles north of La Ventura, common locally on alkaline flat, prostrate, Johnston 7648. SAn Luis Potosi: San Miguel, alkaline flat, prostrate, Johnston 7617 (TYPE).

A prostrate annual species related to A. elegans. It is known only from the stations cited above in southern Coahuila and adjoining northern San Luis Potosi.

Atriplex argentea Nutt. Gen. Pl. 1: 198 (1818).

Atriplex expansa Wats. Proc. Am. Acad. 9: 116 (1874).

Chinuahua: Juarez, valley of the Rio Grande, Sept. 8, 1888, Pringle 1996.

A weedy annual species widely distributed in the western United States.

Atriplex elegans (Moq.) Dietr. Synop. 5: 537 (1852).

Obione elegans var. radiata Torr. Bot. Mex. Bound. 183 (1859).

Chrmuahua: Plains near Chihuahua, Aug. 28, 1885, Pringle 670; Rio Santa Maria east of Corralitos, Aug. 1852, Thurber 715.

Ranging from western Texas to California and south into Sonora and Chihuahua. It has been repeatedly collected on the Texan bank of the river in the Rio Grande Valley below El Paso.

Atriplex texana Wats. Proc. Am. Acad. 9: 113 (1874).

Obione elegans var. tuberculosa Torr. Bot. Mex. Bound. 133 (1859).

Coahuila: 4 mi. southwest of Hermanas, saline flats south of Rio Salado, Johnston 7075; Cuatro Cienegas, 1939, Marsh 2040; 9 mi. east of Cuatro Cienegas, saline soil near road, Johnston 7106.

Extending westward into our area from southern Texas.

Atriplex muricata Humb. \& Bonpl. ex Willd. Sp. Pl. 4: 959 (1806).

Atriplex glomerata Wats. ex Standl. No. Am. Fl. 21: 54 (1916), Bull. Torr. Bot. Cl. 44: 424 (1917).

Vernacular name: Quelitillo.

CoAнuil.A: Castillon, prostrate mats about corrals, Johnston $\mathcal{E}$ Muller 1272; Cuatro Cienegas, 1939, Marsh 2015; $7 \mathrm{mi}$. south of Hipolito, heavy soil on desert plain, Johnston 7244; Saltillo, Sept. 1898, Palmer 290; Parras, April 1880, Palmer 1156 (isotype of A. glomerata); La Punta, $6 \mathrm{mi}$. south of Fraile, silty valley bottom, Johnston 7321. Zacatecas: Between San Tiburcio and Cardona, valley floor, Johnston 7369.

Extending north into our area from central Mexico. A prostrate plant with dentate oblanceolate leaves. 
Atriplex semibaccata R. Br. Prodr. 406 (1810).

Coahuila: Saltillo, roadside, 1939, Frye \& Frye 2496.

An Australian species, first introduced as a forage plant and now widely established from California to Texas.

Eurotia lanata (Pursh) Moq. Chenop. Enum. 81 (1840).

Conhuila: Carneros Pass area, July 1880, Palmer 1164; valley just southwest of Carneros Pass, frequent bush 1-3 ft. tall, valley floor, Johnston 7300; $10 \mathrm{mi}$. south of Carneros Pass, common bush in valley, 2-3 ft. tall, Johnston 7652; between Agua Nueva and Encarnacion, shrub 5 ft. tall, Dec. 15, 1848, Gregg 560.

This shrub has been collected in the high country of northern Chihuahua but otherwise is known from Mexico only in the valleys just south of Carneros Pass. Our plants belong to var. subspinosa (Rydb.) Kearney. It is widely distributed in the western United States.

Bassia hyssopifolia (Pallas) Kuntze, Rev. Gen. 1: 547 (1891).

An Asiatic herb now widely established in trans-Pecos Texas and southern New Mexico. It has been collected along the Rio Grande above and below El Paso and is most certainly to be expected in adjoining northern Chihuahua.

Corispermum nitidum Kit. in Schultes, Oesterr. Fl. ed. 2. $1: 7$ (1814).

Chinuahua: Los Medanos, 1935, LeSueur 285; Cantarrecio, Oct. 1852, sand hills, Thurber 811 .

Widely distributed in sandy places in the middle United States and south to Texas and Arizona.

Allenrolfea occidentalis (Wats.) Kuntze, Rev. Gen. 2: 546 (1891).

Coahuila: Cuatro Cienegas, Marsh 2077; 3 mi. south of Cuatro Cienegas, low shrub on salt-lands, White $1915 ; 4 \mathrm{mi}$. west of Cuatro Cienegas, abundant bush $1-4 \mathrm{ft}$. tall on saline flats, Johnston 7139; Laguna de Jaco, succulent usually decumbent bush becoming $4 \mathrm{ft}$. tall, salt flats at south end of lake, Johnston \& Muller 1084; Laguna del Rey, common on saline flats, $1 \mathrm{dm}$. tall, Stewart 3024; Parras, 1880, Palmer 1166; Laguna Viesca, $7 \mathrm{mi}$. northeast of Viesca, shrub 4-7 ft. tall on saline flat, Johnston 7733; just west of Viesca, saline soil, decumbent, 12-16 inches tall, locally abundant, Johnston 7737 .

A leafless very succulent bush growing only in very saline soils with a perennial source of subsurface water. Widely distributed in the western United States. The plant has been collected in the Rio Grande Valley below El Paso and is doubtless present also in northern Chihuahua.

Suaeda mexicana Standl. Field Mus. Publ. Bot. 4: 203 (1929).

Coahuila: $3 \mathrm{mi}$. west of Cuatro Cienegas, saline flat, 1-4 ft. tall, Johnston 7127; $1 \mathrm{mi}$. west of Anteojo, west of Cuatro Cienegas, gypsiferous saline clays near foot of gentle slope, plant erect, pale green, 1-3 ft. tall, Johnston 8870; Cuatro Cienegas, 1937, Marsh 2071; salt-lands $3 \mathrm{mi}$. south of Cuatro Cienegas, 1939, White 1917. San Luis Potosi: Hacienda Angostura, alkaline plain near San Bartolo Station, July 15, 1891, Pringle 3788 (ISOTYPE).

A glabrous pale green plant 1-4 ft. tall, mostly branched at the base and with numerous erect elongate stems. It appears to be a halophytic gypsophile. It is one of a number of species known from the saline gypseous plains near Cuatro Cienegas and elsewhere only from the similar habitats on Hacienda Angostura in eastern San Luis Potosi. 
Suaeda jacoensis Johnston, Jour. Arnold Arb. 24: 228 (1943).

Cолнuila: Salt-flats at southeast end of Laguna de Jaco, frequent, light green, erect, none seen over $1 \mathrm{ft}$. tall, Johnston $\mathcal{E}$ Muller 1087; Laguna de Jaco, salt flats at southeast end of lake, fairly common, erect, 1-3 dm. tall, Stewart \& Johnston 1975 (TYPE), 1976.

A plant less than $1 \mathrm{ft}$. tall, with numerous subsimple slender stems arising from a branched base. The root may become coarse, woody, and obviously long-persistent, but most of the plants seen appeared to be annuals. The species is related to $S$. mexicana, from which it differs in shorter more slender usually purplish and somewhat verrucose stems and irregularly cristate and keeled mature calyx-lobes. It grows in somewhat gypseous very saline soil and is known only from the type-locality.

Suaeda Palmeri (Standl.) Standl. Field Mus. Publ. Bot. 8: 10 (1930).

Dondia Palmeri Standl. No. Am. Fl. 21: 91 (1916).

Vernacular names: Saladillo; Jaboncillo.

CoAhuila: Hermanas, 1939, Marsh 1641; 4 mi. west of Cuatro Cienegas, common bush on saline flats, erect, 1-3 ft. tall, Johnston 7138; Divisadero, about 11 mi. west of Cuatro Cienegas, a common bush on flats and on the long gentle slopes nearly up to the base of the mountains, confined to saline gypseous clays, Johnston 8864; near Cienega Grande, May 18, 1847, Gregg; $3 \mathrm{~km}$. southeast of Las Margaritas, Valle Delicias, common on flats, $1 \mathrm{~m}$. tall, Stewart 2950; Parras, June 1880, Palmer 1158 (ISOTYPE) ; $4 \mathrm{mi}$. north of Peña, alkaline valley-slope, dense bush, 2-4 ft. tall, Johnston 7719 ; valley $8 \mathrm{mi}$. north of Avalos, saline flats, common bush, 3-5 ft. tall, Johnston 7339. Zacatecas: Cedros, 1908, Lloyd 133.

A bush 1-5 ft. tall, with a woody base and at times a small trunk and distinctly ligneous twiggy ascending branches. It is frequently a common shrub over large areas, and where it has been seen it is characteristic of silty saline and gypsiferous soils. It is not an ordinary halophyte and is not confined to flats where soil moisture is readily available. It is frequently very common on dry silty slopes and in dry valleys below exposures of Upper Cretaceous shales and clays.

Suaeda nigrescens Johnston, Jour. Arnold Arb. 24: 228 (1943).

Coahulla: 4 mi. southwest of Hermanas, saline flats south of the Rio Salado, Johnston 7074; valley $8 \mathrm{mi}$. north of Avalos, saline flats, Johnston 7340; 12 mi. north of La Ventura, common on saline flats, bush 1-2 ft. tall, Johnston 7650 (TYPE).

Saline flats of eastern Coahuila south to northern San Luis Potosi. A dark green plant with slender much branched decumbent or ascending stems. The branchlets are covered with a minute brownish pubescence.

Suaeda nigrescens var. glabra Johnston, Jour. Arnold Arb. 24: 229 (1943).

Coahuila: Laguna del Rey, saline flats, common, Stewart 3023; about $30 \mathrm{mi}$. south of Sierra Mojada, 1937, Wynd 771. Chrnuanua: Meoqui, 1935, LeSueur 197.

Ranging from western Coahuila and eastern Chihuahua north into transPecos Texas (Rio Grande Valley) and southern New Mexico, and apparently also in southeastern Texas. Differing from typical $S$. nigrescens in having glabrous and more or less glaucous branchlets.

Suaeda suffrutescens Wats. Proc. Am. Acad. 9:88 (1874).

Coahuila: Saline gently sloping plain between San Vicente and Laguna de Jaco, decumbent perennial, Johnston $\mathcal{E}$ Muller 1071; south end of Laguna Jaco, saline flats, 
decumbent, Johnston \& Muller 1082; Americanos, apparently saline flat at base of gypsum beds, 1-2 ft. tall, branches numerous, at first ascending but in old age more or less sprawling, cortex of perennial root black, Johnston 9386; south of Laguna Leche, saline gypseous soil, erect or ascending, 1-3 ft. tall, grayish, Johnston 8269. Chinuahua: Near Juarez, Aug. 28, 1886, Pringle $1144 ; 5-8$ mi. south of Ojinaga, outwash from saline and gypseous clay-banks, Johnston \& Muller 1449, Johnston 8001.

The common and widely distributed Suaeda in trans-Pecos Texas, ranging north along the Pecos and Rio Grande into southern New Mexico, and extending south into eastern Chihuahua and western Coahuila. If not restricted to saline gypseous soils it at least appears to favor that substratum.

Suaeda suffrutescens var. detonsa Johnston, Jour. Arnold Arb. 24: 230 (1943).

Vernacular name: Saladillo.

CoAhuila: $3 \mathrm{mi}$. west of Cuatro Cienegas, saline gypseous flat, loosely and widely branched, 1--5 ft. tall, Johnston 7128 (TYPE) ; 3 mi. south of Cuatro Cienegas, saltlands, low shrub, White 1913; Cuatro Cienegas, Marsh 2042; Perros Bravos, shrubby, 3 ft. tall, abundant, Sept. 20, 1848, Gregg 458; Saltillo, July 1880, Palmer 1167; 5 mi. west of Viesca, saline and probably gypseous slope, erect, Johnston 7739 . Durango: Bolson de Mapimi (Rio Nazas to Mapimi), April 15, 1847, Gregg 449.

Known only from our area. Differing from typical $S$. suffrutescens in having the leaves green and glabrous, rather than pubescent and gray. It appears to be a larger and more widely branched bush, growing in the area to the south and southeast of that occupied by typical S. suffrutescens. Gregg reports that its ashes are rich in alkali and are used in soap-making.

Salsola Kali L. var. tenuifolia Tausch, Flora 11:326 (1828).

Loesener, Repert. Sp. Nov. 16: 201 (1919), reports that Endlich, no. 241, collected this plant between Mapimi and Ojuela, Durango, sometime during the period 1903-1906. I have seen no specimens from the area. The plant is such a common weed along roadsides and in fields in southern New Mexico and in the Rio Grande valleys below El Paso that it must also be present in adjoining Chihuahua.

\section{AMARANTHACEAE}

Celosia Palmeri Wats. Proc. Am. Acad. 18: 143 (1883).

Coahulla: Santa Anna Canyon, July 15, 1936, Marsh; 12 mi. north of Monclova, under bushes on silty valley soil in mesquite-thicket, stems straight, spreading or nearly erect, Johnston 7191; Monclova, Aug. 1880, Palmer 1148 (TYPE).

Known only from eastern Coahuila.

Amaranthus Berlandieri (Moq.) Uline \& Bray, Bot. Gaz. 19: 268 (1894).

Coahuila: On plain a mile southeast of Ocampo, one plant near a mogote, Johnston $8886 \mathrm{~A}$.

Ranging in central and southern Texas south into adjacent northeastern Mexico.

Amaranthus Warnockii sp. nov.

Herba parva glabra viridis 5-20 (raro ad 30) $\mathrm{cm}$. alta basi ramosa; ramis 1-5 decumbentibus ascendentibus vel erectis pallidis $1-4 \mathrm{~mm}$. crassis simplicibus vel ascendenter ramosis; foliis numerosis oblanceolatis longe petiolatis, lamina haud crassa $1-3.5 \mathrm{~cm}$. longa $5-10 \mathrm{~mm}$. lata medium versus vel 
paullo supra medium latiore deinde basim versus in petiolum (lamina breviorem vel subaequilongum ) $1-3 \mathrm{~cm}$. longum gradatim attenuata, subtus pallidiore minute albo-tuberculata, nervis pinnatis utrinque 5 vel 6 pallidis ascendentibus prominulis margines laminae haud attingentibus donata, margine plana vel perinconspicue crispa et albo-marginata; cymis bisexualis densis parvis 2-8 $\mathrm{mm}$. longis subsessilibus, imam ad basim caulium conspicue aggregatis, alibi 1 vel 2 in axillis foliorum enatis, ramis cymae congestis rigidis flexuosis strictis bracteosis cartilagineo-incrassatis cum fructibus persistentibus tarde deciduis; floribus masculis paucis basi cymae gestis sessilibus mox deciduis, lobis 5 oblanceolatis ad $1.5 \mathrm{~mm}$. longis haud induratis, filamentis 3 vel 4 ad $1.4 \mathrm{~mm}$. longis, antheris $0.9 \mathrm{~mm}$. longis oblongis; floribus femineis sessilibus pluribus, lobis perianthii 5 spathulato-oblanceolatis $1-1.5 \mathrm{~mm}$. longis infra medium incrassatis pallidis supra medium in lamina ca. $0.5 \mathrm{~mm}$. lata viridi margine conspicue alboscariosa dilatatis; utriculis maturis compressis indehiscentibus persistentibus $1-1.2 \mathrm{~mm}$. longis $0.8-0.9 \mathrm{~mm}$. latis tuberculatis vel raro sublevibus in ambitu ovato-orbiculatis, stylis 2 raro $3 \mathrm{ca} .1 \mathrm{~mm}$. longis infra medium incrassatis; seminibus brunneis sublevibus.

CoAhuila: $12 \mathrm{mi}$. north of Monclova, silty valley floor in mesquite thicket, Johnston 7076; 1 mi. southeast of Ocampo, silty plain near mogote, Johnston 8886 (TYPE, Gray Herb.) ; valley floor east of Puerto Caballo, dried bed of ephemeral charco, Johnston 8329; a mile west of Bufido, silty valley slope, Johnston \& Muller 844; west of San Rafael, north base of Sierra Cruces, silty valley flat, Johnston \& Muller 1039 A; $10 \mathrm{mi}$. south of Jaco, silty flat by mogote, Johnston \& Muller 1124. Durango: Near Coahuilan boundary, $31 \mathrm{mi}$. north of Zaragoza, silty valley soil, Shreve 8828. Texas: Baldy Peak, Glass Mts., Brewster Co., abundant locally in a sheep-pen tract on lower slopes, July 4, 1940, Warnock 14.

Known only from our area and from a single collection in trans-Pecos Texas. A small decumbent or sprawling annual herb of silty valley soils and particularly of those places temporarily flooded after rains. It usually is locally common in open places, frequently near mogotes but not in their shade. I noted but did not collect the species just north of Zenzontle, Coahuila.

The species is evidently a close relative of $A$. crassipes Schlechtend. of Florida and the West Indies. The present plant of northern Mexico and trans-Pecos Texas differs from $A$. crassipes in its elongate somewhat thinner leaves, oblanceolate rather than ovate leaf-blades, less elongate and more slender (never long and trailing) stems, and smaller more compact cymes conspicuously crowded at the base of the stems. Among the Texan and Mexican species A. Warnockii can be confused only with $A$. scleropoides Uline \& Bray, of central parts of Texas east of the Pecos. That latter species has leaves similar to those of $A$. Warnockii in form, texture, and size, but it differs in having regularly 3 styles, a circumscissile rather than indehiscent utricle, more obese cyme-branches, and cymes that are rarely conspicuously aggregated at the stem-bases. Furthermore, A. scleropoides is usually an erect herb, while $A$. Warnockii is decumbent or nearly prostrate or rarely with only the primary stem erect.

With this species it is a pleasure to associate the name of Barton $\mathrm{H}$. Warnock of Alpine, Texas. His many collections from Brewster County, 
Texas, deposited at the Gray Herbarium, have been very useful in the preparation of this series of papers. Especially interesting are his numerous collections from the Glass Mts., which have revealed that area as the northern limit of many characteristic plants of western Coahuila.

Amaranthus Torreyi (Gray) Benth. ex Wats. Bot. Calif. 2:42 (1880).

Amblogyne Torreyi Gray, Proc. Am. Acad. 5: 167 (1861).

Sarratia Berlandieri var. emarginata Torr. Bot. Mex. Bound. 179 (1859).

Amaranthus Pringlei Wats. Proc. Am. Acad. 22: 476 (1887).

Amaranthus Bigelovii Uline \& Bray, Bot. Gaz. 19: 271 (1894).

Amaranthus Bigelovii var. emarginata (Torr.) Uline \& Bray, Bot. Gaz. 19:271 (1894).

Coahuila: Igneous hill near Santo Domingo, Wynd \& Mueller 478; San Antonio de los Alamos, arroyo at base of cliffs, Johnston $\mathcal{E}$ Muller 847; north base of Sierra Cruces, arroyo-bank, Johnston \& Muller 1045; Sierra Cruces, Cañon Tinaja Blanca, under ledge in canyon, Johnston \& Muller 233; San José, southeast of Sierra Cruces, slope of basalt hill, Johnston \& Muller 982. Chinuahua: 11 mi. south of Ojinaga, limestone ledge in deep arroyo, Johnston 8038; llano 7 mi. northeast of La Morita, grassy plain, Johnston 7972; hills northwest of Chihuahua, Sept. 26, 1886, Pringle 795 (TYPE).

Ranging from trans-Pecos Texas west to southern Arizona and south into our area. In all recent works this species has been called $A$. Pringlei, but that is properly a synonym of A. Torreyi, a name almost universally misapplied to a very different species of sandy soil on the high plains of the middle United States, but actually belonging to our present species. The history of Amaranthus Torreyi begins with Gray's enumeration of the plants collected by Xantus in southern Baja California, where the following is published, "100. Amblogyne (Sarratia) Torreyi. Sarratia Berlandieri \& var. emarginata, Torr. l. c. non Moq.*" The asterisk refers to a footnote on page 169, where the additional notes are given, "4. A. Torreyi (Sarratia Berlandieri, cum var. emarginata, Torr. 1. c., non Moq.): dioica; foliis ovato-oblongis seu oblongo-lanceolatis; glomerulis paniculato-spicatis et axillaribus; bracteis sepalisque masculis cuspidato-acuminatis; sepalis $q$ ima basi coalitis subaequalibus obovato-spathulatis uninerviis, nervo simplici seu leviter pinnatim ramoso, apice rotundato integerrimo retuso vel emarginato. - On the Mexican border from the Rio Grande (Dr. Bigelow, Dr. Parry, etc.) to Lower California, Xantus, supra, no. 100. A variety with linear or oblong-linear leaves and virgate spikes was collected near the sources of the Nebraska, by Mr. Henry Engelmann." Gray seems to be correct in treating Sarratia Berlandieri and S. Berlandieri var. emarginata of Torrey (1859) as conspecific. The first is based upon a collection by Bigelow from Cibolo Creek, at the east end of the Chinati Mts., Texas, and the latter upon material from "Camp Green" collected by Parry, apparently in the Rio Grande Valley somewhere between Lajitas and Boquillas Canyon. Upon these same collections of Bigelow and Parry, Uline \& Bray (1894) established A. Bigelovii and A. Bigelovii var. emarginata. In his treatment of the genus, Standley, No. Am. Fl. 21: 109 (1917), recognized $A$. Bigelovii and treated var. emarginata as a synonym of it. The Baja California material, Xantus 100, mentioned by Gray when 
he published the name Amblogyne Torreyi, was subsequently described as Amaranthus Torreyi var. suffruticosus by Uline \& Bray, Bot. Gaz. 19: 272 (1894). This trinomial Standley, No. Am. Fl. 21: 106 (1917), later cited as a synonym of $A$. Watsoni Standl. The collection by Engelmann, mentioned by Gray, is the plant of the middle United States which authors, following Uline \& Bray, Bot. Gaz. 19: 272 (1894), and later Standley, No. Am. Fl. 21: 107 (1917), have accepted as true A. Torreyi. This seems obviously incorrect, for Gray's comments on Engelmann's collections, as well as his annotations of the collection itself, show he did not consider the specimen typical of his species. The fact that Gray named the species for Torrey and gave great prominence to the Bigelow and Parry specimens treated in Torrey's Botany of the Mexican Boundary shows clearly what he considered the nucleus of his species. Standley, No. Am. Fl. 21: 107 (1917), evidently recognized this fact, for although he applied the name A. Torreyi to the plant of the high plains of the middle United States, he cites "Sarratia Berlandieri Torr. Bot. Mex. Bound. Survey 179. 1859" as a synonym of Amaranthus Torreyi and even gives Cibolo Creek as the type locality of the species.

When Gray published Amblogyne Torreyi he gave an ambiguous description and mentioned four collections, one from the Great Plains, one from Baja California, and two from the Rio Grande. The specimen from the Great Plains he obviously considered as atypical of his species. The name he chose for the species, his bibliographic references, and half the total specimens mentioned refer to our present plant, later described as A. Pringlei Wats. and A. Bigelovii Uline \& Bray. Unless these facts are to be ignored and the name applied to the plant of Sonora and Lower California now called A. Watsoni Standl., the name Amaranthus Torreyi must be applied in the sense here accepted.

Amaranthus Palmeri Wats. Proc. Am. Acad. 12: 274 (1877).

Vernacular name: Quileto.

Coahuila: North end of Sierra Cruces, dry open bed of arroyo, erect, up to $6 \mathrm{ft}$. tall, Johnston \& Muller 1050; Bolson de Lipanes, between El Almagre and Sierra de Leja, edge of mogote, erect, becoming $5 \mathrm{ft}$. tall, Johnston $\mathcal{E}$ Muller 1252. Chinuahua: Grassy plain $7 \mathrm{mi}$. northeast of La Morita, Johnston 7972A; Lake Santa Maria, 1899, Nelson 6420; 26 mi. north of Camargo, road to Las Delicias, White 2288.

Texas to California and south through Sonora, Chihuahua, and western Coahuila into central Mexico. The only dioecious species of Amaranthus known from our area.

Amaranthus hybridus L. Sp. Pl. 990 (1753).

Vernacular name: Quelito de Cochino.

Coahuila: Saltillo, common plant in cultivated ground, 1898, Palmer 421; Buenavista, south of Saltillo, frequent, 3 ft. tall, July 24, 1848, Gregg 283.

Widely distributed in central Mexico and northward in eastern Mexico into the eastern United States. Usually a coarse plant, a half meter or more in height, and commonly a weed in disturbed ground. The dense, very floriferous, frequently nodding inflorescence is somewhat tawny in color. 
Amaranthus Powellii Wats. Proc. Am. Acad. 10:347 (1875).

Coahulla: Sierras Negras $9 \mathrm{~km}$. south of Parras, Stanford et al. 173. Zacatecas: Valley $15 \mathrm{~km}$. west of Concepcion del Oro, Stanford et al. 505 .

Native in the western United States east to Wyoming, Colorado, and trans-Pecos Texas and extending south into northern Mexico, where it has been most frequently collected in the highlands of Chihuahua and Sonora. Closely related to $A$. hybridus and apparently in former times replacing that species in western parts of the continent. At times it is separated from $A$. hybridus with difficulty, but commonly it may be distinguished by being a more slender and lower plant with much simpler less floriferous inflorescences, having stiffer somewhat longer bracts, and a green rather than tawny color.

Amaranthus retroflexus L. var. salicifolius var. nov.

A varietate typica differt habitu graciliore, planta saepe $2-6 \mathrm{dm}$. alta, laminae foliis lanceolatis saepe 3-4-plo latioribus quam latis.

Coahulla: Parras, 1880, Palmer 2043 (туре, Gray Herb.); Tanque Jerico, north of Potrero del Fuste, under bushes by tank, Johnston 8342A. Texas: Chisos Mts., The Basin, common, Warnock C647; 7 mi. southwest of Marfa, Presidio Co., 1927, Cory 26310; Davis Mts., near Observatory, 1936, Hinckley; Glass Mts., infrequent, 1940, Warnock 17; 10 mi. northeast of Ft. Stockton, Pecos Co., 1934, Cory 9717; 21 mi. north of Ozona, Crockett Co., 1939, Cory 32737, 33353; 19 mi. west of Sonora, Sutton Co., Cory 37937; 29 mi. southeast of Midland, Midland Co., 1942, Cory 40598. Arizona: Fort Apache, 1890, Palmer 587.

Typical A. retroflexus appears to be native in the eastern and southeastern United States, but as an introduced weed it now grows in the western United States as well as in various places in the Old World. In agreement with Standley, Bull. Torr. Bot. Cl. 41: 510 (1914), I have seen no true A. retroflexus from Mexico. To the west of what was probably the original range of true $A$. retroflexus, there is found an endemic variety, here called var. salicifolius, which occurs in west-central and trans-Pecos Texas and apparently also in eastern Arizona, which does range south into the Mexican state of Coahuila. I have seen no specimens of typical A. retroflexus from the parts of western Texas in which var. salicifolius has been collected. The variety does not grow as tall or become such a coarse plant as typical A. retroflexus. Its chief difference, however, is in the shape of the leafblades, which are lanceolate rather than ovate. These are minor differences, but since plants referable to the variety come from a natural geographic area, in which typical $A$. retroflexus appears to be absent, I believe it deserves a name. At times var. salicifolius resembles $A$. Powellii, but it may be readily separated from that species by its pallid inflorescence and obtuse or retuse, rather than acute, perianth-lobes.

Amaranthus blitoides Wats. Proc. Am. Acad. 12: 273 (1877).

Vernacular Name: Quelito.

CoAhuila: Sierra del Carmen, Aug. 21, 1936, Marsh 559; Hermanas, Marsh 2258; La Azufrosa, frequent, Sept. 22, 1848, Gregg 516; Perros Bravos, frequent, Sept. 20, 1848, Gregg 469; Rancho Gallinas, 6 mi. east of Puertecito, disturbed soil in abandoned labor, prostrate, Johnston $8583 ; 5 \mathrm{mi}$. west of El Oro, beside railroad on road to Guimbalete, White 1999 . 
A prostrate plant widely distributed in the western United States and northern Mexico.

Acanthochiton Wrightii Torr. in Sitgr. Rep. Explor. 170. t. 13 (1853).

Chinuahua: Cantarrecio, sands, Oct. 1852, Thurber 806, 809; Samalayuca, sanddunes, LeSueur 278, 280; sandhills south of Samalayuca, Sept. 20, 1886, Pringle 796; Candelaria, sand-dunes, Shreve 9033.

A plant of sandy places ranging from El Paso County, Texas, west to Arizona and south into Chihuahua. The plant is dioecious and the male plants are frequently misidentified as representing an Amaranthus.

Brayulinea densa (Willd.) Small, Fl. S. E. U. S. 394 (1903).

Vernacular Name: Bola de Hilo.

Coahuila: Sierra del Carmen, Aug. 9 and 29, 1936, Marsh 682, 695; Sierra Hechiceros, Cañon Indio Felipe, sandy soil in arroyo, Stewart 48; Sierra Hechiceros, sandy flat east of El Tule, Stewart 492. Chinuahua: Near Coahuilan boundary a mile east of Poza de Villa, silty plain, Johnston 8178; 20 mi. north of San José del Progreso, sandy slopes, Stewart 2351; Sierra Encinillas, near Fierro, sandy hillside, Stewart 732; near Mesteñas, open rock slope, Stewart \& Johnston 2030; near Chihuahua, mesas and arroyos, 1908, Palmer 196. Zacatecas: Concepcion del Oro, stony mesas, 1904, Palmer 312.

Western Texas to Arizona and south into tropical America.

Froelichia gracilis (Hook.) Moq. in DC. Prodr. 132: 420 (1849).

Coahuila: Sierra del Carmen, Cañon Sentenela, Wynd \& Mueller 647; Muzquiz, Marsh 524. Chinuahua: Llano 7 mi. northeast of La Morita, grassy plain, Johnston 7973; Chihuahua, 1935, LeSueur.

Ranging from Texas to Arizona and south into our area. An annual species with a firm slender root and tuberculate fruit.

Froelichia interrupta (L.) Moq. in DC. Prodr. 132: 421 (1849).

Chrnuahua: Chihuahua, 1935, LeSueur 55; Meoqui, 1936, LeSueur 1050.

The above collections, lacking the base of the stem and the root, appear to represent a phase of $F$. interrupta with elongate tomentose leaves. The mature fruit is not armed laterally. The species ranges from western Texas south through Mexico to South America.

Froelichia arizonica Thornber ex Standl. No. Am. Fl. 21: 128 (1917).

CoAhuila: Sierra del Carmen, Aug. 22, 1936, Marsh 580; Yerda Springs, Marsh 285; Caracol Mt., Aug. 1880, Palmer 1142; Puerto San Lazaro, Muller 30491; La Azufrosa, frequent, Sept. 22, 1848, Gregg 510; Saltillo, 1898, Palmer 572; hills 20 mi. west of Saltillo, Shreve $\mathcal{E}$ Tinkham 9832; Carneros Pass area, July 1880, Palmer 1141; Sierra Encantada, Cañon San Enrique, Stewart 1368; Sierra del Pino, Cañon Ybarra, Stewart 1878; Sierra del Pino, La Noria, Johnston \& Muller 475, Stewart 1239; Sierra Hechiceros, Cañon Indio Felipe, Stewart 51; Picacho de Noche Buena, Johnston $\mathcal{E}$ Muller 175; Sierra Cruces, $5 \mathrm{~km}$. northeast of Santa Elena, Stewart 610; near San José, southeast of Sierra Cruces, Johnston $\mathcal{E}$ Muller 988; San Antonio de los Alamos, Johnston \& Muller 929; Sierra Planchada, Cañon Gringo, Stewart 1037; Aguaje Pajarito, west end of Sierra Fragua, Johnston $8803 ; 4$ mi. west of Cuatro Cienegas, Johnston 7154; Puerto Ventanillas, Stewart 2788; 2 km. south of Las Delicias, Stewart 2961. Chinuahua: Rancho El Pino, southeast of Sierra Rica, Stewart 2412; 12 km. north of San José del Progreso, Stewart 2340; Sierra Encinillas, Fierro, Stewart 744; Sierra Virulento, east base of sierra, Johnston 8079; near Mesteñas, Stewart $\mathcal{G}$ Johnston 2029; $11 \mathrm{mi}$. northeast of Camargo, Johnston 7919. 
Dry rocky places on hillsides and along arroyos, in calcareous and volcanic areas. A perennial with a rather fleshy tap-root and one to several strict erect subsimple stems becoming 4-12 dm. tall. The persistent base of the stems becomes somewhat woody and forms a small sparsely and strictly branched caudex. The bracts of the inflorescence are usually black. The stone-like fruiting perianth bears spines or conic protuberances on each side. Ranging from trans-Pecos Texas to Arizona and south into our area.

Tidestromia lanuginosa (Nutt.) Standl. Jour. Wash. Acad. 6: 70 (1916).

Coahuila: Sierra del Carmen, Sept. 12, 1936, Marsh 843; Monclova, Marsh 1818; Cuatro Cienegas, Marsh 2026; Mesillas, Sept. 19, 1838, Gregg 450; 6 mi. north of La Ventura, Johnston $7635 ; 5 \mathrm{mi}$. east of Penquitas, road between Santa Elena and Tanque La India, Johnston \& Muller 797; $2 \mathrm{~km}$. east of San Juan, southwest base of Sierra Cruces, Stewart 816; valley-floor east of Puerto Caballo, Johnston 8334; Potrero del Cuervo Chico, Johnston 8577; 25 mi. east of Americanos, Wynd 752; Americanos, Johnston 9377; San Lorenzo de la Laguna, 1880, Palmer; Torreon, 1898, Palmer 469. Chinuahua: 5 mi. south of Ojinaga, Johnston 8002; Samalayuca, LeSueur 279; sandhills near Laguna Guzman, Hartman 727; Chihuahua, Sept. 27, 1902, Pringle 11144; $10 \mathrm{mi}$. west of El Pozo on road to Santa Eulalia, White 2446. Zacatecas: Cedros, Kirkwood 114.

Widely distributed in the southwestern United States and extending south into Tamaulipas, Zacatecas, and Sinaloa. A generally distributed herb in our area, in sandy places, valley silts, and on gypsum, becoming most abundant in disturbed soils.

Tidestromia tenella Johnston, Jour. Arnold Arb. 20: 234 (1939).

Coahuila: 1 mi. north of Noria San Juan, south of Laguna del Rey, desert flat, plant succulent, yellowish green, Johnston 7822 (TYPE).

Known only from the type collection. Most closely related to T. carnosa, but a smaller and more slender plant with barbellate rather than coarsely branched trichomes. The plant is probably gypsophilous.

Tidestromia carnosa (Steyerm.) Johnston, Jour. Arnold Arb. 24: 232 (1943).

Cladothrix lanuginosa var. carnosa Steyerm. Ann. Mo. Bot. Gard. 19: 389 (1932).

Chinuahua: $8 \mathrm{mi}$. south of Ojinaga, slopes and flats with Suaeda, fleshy yellowish green prostrate plant, Johnston $\mathcal{E}$ Muller $1447 ; 5 \mathrm{1} / 2$ mi. south of Ojinaga, outwash from saline shales, Johnston 8003.

South of Ojinaga confined to outwash from Upper Cretaceous gypseous saline shales and clays. Otherwise known only from Brewster County, Texas, where it grows in geologically similar formations about the base of the Chisos Mts.

Tidestromia suffruticosa (Torr.) Standl. var. coahuilana Johnston, Jour. Arnold Arb. $24: 232.1943$.

Coahutla: Sierra Cruces, 5 mi. north of Santa Elena, Johnston \& Muller 1014 (TYPE); Sierra Cruces, 5 km. west of Picacho San José, Stewart 820; Sierra del Pino, Cañon Ybarra, Stewart 1855; Lomas del Aparejo, east side of Llano de Guaje, Johnston $\mathcal{E}$ Muller 773; south end of Sierra del Pino, northeast of Armendais, Johnston $\mathcal{E}$ Muller 362; west base of the grade over Cuesta Zozaya, Muller 3287, Johnston 9300; Aguaje Pajarito, west end of Sierra Fragua, Johnston 8677; Cañon de Jara, 3 mi. west of Socorro, Johnston 8844; Sierra de la Paila, Oct. 1910, Purpus 4927.

Growing in dry, rocky, usually moderately gypseous soils along the base 
of limestone sierras. Although found in various parts of Coahuila, chiefly western, the plant has a disrupted distribution, perhaps because of special soil requirements. When present the plant is rather common locally. The variety coahuilana is known only from Coahuila and is closely related to typical T. suffruticosa (Torr.) Standl., of southeastern New Mexico and trans-Pecos Texas, from which it is distinguished by its denser indument, more shrubby stems, and glabrate flowers. Typical T. suffruticosa has been collected near Boquillas and Terlingua in the Big Bend area of Texas and can be expected in adjacent northern Coahuila.

Tidestromia gemmata Johnston, Jour. Arnold Arb. 24 : 233 (1943).

Coahuila: South of Matrimonio Viejo, gypsiferous shales, Johnston 9363 (TYPE) ; just east of Americanos, cemented gravels capping gypsum, Johnston 9379; $20 \mathrm{~km}$. southeast of Rancho Alegre, road to Acatita, common, Stewart 2668. TExas: Boquillas, Brewster Co., Sept. 4, 1937, Marsh 310.

A perennial species strongly simulating the widespread T. lanuginosa in general appearance, but quickly distinguished from that annual herb by its coarse root and the conspicuous white woolly buds on its caudex. Known only from the collections listed above. The species is probably gypsophilous.

Tidestromia rhizomatosa Johnston, Jour. Arnold Arb. 24: 233 (1943).

Coahuila: Saline gypseous flats just east of El Anteojo, west of Cuatro Cienegas, Johnston 8873 (TYPE).

A prostrate perennial with fleshy more or less reflexed leaves which spreads by slender smooth rhizomes. Known only from the type locality, where it is locally very common.

Gossypianthus lanuginosus (Poir.) Moq. in DC. Prodr. 122: 337 (1849).

Coahuila: $12 \mathrm{mi}$. north of Monclova, silty soil in mesquite thicket, Johnston 7188 . Chrnuahua: Plains near Chihuahua, about railroad shops, Aug. 22, 1885, Pringle 689.

Ranging in central and southern Texas south into Tamaulipas, Coahuila, and Chihuahua; West Indies. Frequently confused with Brayulinea, but quickly distinguished by its persistent basal rosette of leaves and the bristly upper leaf-surfaces.

Alternanthera repens (L.) Kuntze, Rev. Gen. 2 : 536 (1891).

Vernacular name: Ojo de Pollo.

Conhuila: Don Martin Dam, White 1377; Sierra del Carmen, Aug. 9, 1936, Marsh 683; Hac. Encantada, Stewart 1734; Saltillo, 1898, Palmer 562; Fraile, Stanford et al. 270. Chinuahua: Chihuahua, waste-places, river-banks and roadsides, common, 1908, Palmer 175; northwest of Chihuahua, Oct. 21, 1885, Pringle 295; Bachimba, Nov. 1852, Thurber 848. Zacatecas: Valley $18 \mathrm{~km}$. west of Concepcion del Oro, Stanford et al. 579 .

A creeping plant frequenting wet soils and disturbed moist places. Ranging from North Carolina to Arizona and south into tropical America.

Gomphrena Haageana Klotzsch, Allg. Gartenz. 21: 297 (1853).

Coahuila: Muzquiz, Marsh 14; Palm Canyon, Muzquiz, Marsh 371; Soledad, 1880, Palmer; Cañon Bocatoche, common on open grassy valley floor, bracts orange to red, Muller 3118 .

Ranging in eastern Coahuila and adjacent Texas (Val Verde to Brewster Counties); reported from Nuevo Leon. 
Gomphrena decumbens Jacq. Hort. Schoenbr. 4: 41 (1804).

Coahuila: San Lorenzo Canyon, 6 mi. southeast of Saltillo, prostrate on grassy areas, showy, bracts bright rose-color with white base, 1904, Palmer 389. Chinuahua: Chihuahua, edge of river, a few plants only, bracts showy, rose-colored, 1908, Palmer 189.

Nuevo Leon and southeastern Coahuila south into central Mexico and South America. Extending north in Durango and Chihuahua, but apparently as an introduced weed.

Gomphrena nitida Rothr. Bot. Wheeler Survey 233 (1878).

Coahuila: Sierra del Carmen, Sept. 9, 1936, Marsh 714; Sierra Hechiceros, Cañon Indio Felipe, dry sandy arroyo, Stewart 65; Sierra Cruces, about Tinaja Blanca, sandy arroyo, bracts white to pink, Stewart 336, 1132, 1948. Chinuahua: Sierra Hechiceros, Rancho Encampanada, edge of creek, not abundant, pink, Stewart 198; 5 mi. north of Escobillas, rocky slopes, frequent, pinkish, Stewart 2374A; east base of Sierra Virulento, arroyo bottom, Johnston 8092; Sierra de Enmedia, 1890, plains, Nelson 6471; Majalca, 1935, LeSueur 19, 20; west base of Sierra Santa Eulalia, common on rocky slope, mostly white, Stewart $\mathcal{E}$ Johnston 2109; rocky hills near Chihuahua, Sept. 1885, Pringle 315; Jimenez, Rio Florido, White 2083; Parral, 1898, Goldman 114.

Trans-Pecos Texas (Chisos and Davis Mts.) through southern New Mexico to southeastern Arizona, and south to central Mexico. The range of this species appears to center in the uplands along the western Sierra Madre.

Dicraurus leptocladus Hook. f. in Benth. \& Hook. Gen. Pl. 3: 43 (1880).

Coahuila: Sierra del Carmen, Sept. 8, 1936, Marsh 797; Saltillo, 1898, Palmer 297; near Saltillo, Oct. 4, 1905, Pringle 13604; Sierra del Pino, Cañon Ybarra, dry hillside, Stewart 1876; Sierra Cruces, near Santa Elena, clambering up through bushes to $6 \mathrm{ft}$., Johnston \& Muller 239, Stewart 278; Sierra Parras, Aug. 1910, Purpus 4979. Chinuahua: Rancho El Pino, southeast of Sierra Rica, sunny slope, Stewart 2569; $7 \mathrm{mi}$. northwest of Temporales de Honorato, supported by bushes in mogote, reaching $25 \mathrm{dm}$. in height, Stewart \& Johnston 1991; hills near Chihuahua, Sept. 30 and Oct. 24, 1885, Pringle 345; Jimenez, Nov. 1852, Thurber 840. Durango: Mapimi, Oct. 1898, Palmer 529.

A shrubby plant of silty valley soils and of rocky soils on the lower slopes and canyons. Commonly growing up through shrubs and supported by them, attaining one or two meters in height. Ranging from trans-Pecos Texas, chiefly in the Rio Grande Valley, south through our area to Zacatecas and San Luis Potosi.

Iresine heterophylla Standl. Contr. U. S. Nat. Herb. 18: 95 (1916).

Coahuila: Sierra del Carmen, Cañon Sentenela, Wynd \& Mueller 526; Yerda Springs, Marsh 352; volcanic hill $2 \mathrm{~km}$. east of Cañon Milagro, east of the Sierra Guajes, hillside, erect, not common, Stewart 1511; Saltillo, 1898, Palmer 288; Sierra Hechiceros, Cañon Indio Felipe, Stewart 29, 70, 83; Sierra Cruces, Cañon Tinaja Blanca, clambering in shrubbery, common, Stewart 1139; San Antonio de los Alamos, base of tuff cliffs, Johnston 8271. Chinuahua: Sierra Rica, Cañon Madera, shade in canyon, frequent, Stewart 2521; rocky hills near Chihuahua, shade of cliffs, Sept. 22, 1885, Pringle 348; Bachimba, Nov. 1852, Thurber 838.

Western Texas to Arizona and south to central Mexico.

Iresine Calea (Ibánez) Standl. Contr. U. S. Nat. Herb. 18: 94 (1916).

Iresine laxa Wats. Proc. Am. Acad. 21: 454 (1886).

Durango: Sierra Guadalupe canyon about $4 \mathrm{mi}$. west across the valley of the Aguanaval from Jimulco, April 27, 1885, Pringle 141 (type of I. laxa). 
Ranging from northeastern Durango, Sonora, and Baja California south to Costa Rica. Pringle's collection cited above, the type of $I$. laxa, is labeled as from "mountains, Jimulco, Coahuila, April 27, 1885." Pringle's published diaries, however, clearly show that the collection was obtained at the locality I have recorded above.

\section{NYCTAGINACEAE}

Selinocarpus chenopodioides Gray, Am. Jour. Sci. II. 15: 262 (1863).

Ammocodon chenopodioides Standl. Jour. Wash. Acad. 6: 631 (1916).

Chinuahua: Pass $10 \mathrm{mi}$. south of Mula, one plant on alluvial terrace, erect, Johnston 8044; Juarez, dry calcareous bluffs, Sept. 26, 1902, Pringle 11143; foothills towards Lake Santa Maria, fl. purple, April 9, 1852, Wright 1707 in pt.; northwest of Chihuahua, 1935, LeSueur 394; Santa Eulalia plains, Aug. 18, 1885, Wilkinson (US); plains near Chihuahua, Aug. 15, 1885, Pringle 652.

Trans-Pecos Texas (Brewster Co. west) to southern Arizona and south into Chihuahua. An erectly branched herb with tuberous roots.

Another herbaceous Selinocarpus, S. diffusus Gray, may be found in northern Chihuahua or Coahuila. At the Gray Herbarium there is a collection labeled "Bluffs of Rio Grande, 1881, Havard 90." In his published report, Havard, Proc. U. S. Nat. Mus. 8: 478 (1885), mentions the species as growing on bluffs along the Rio Grande, presumably in either Presidio or Brewster County, Texas. The species is otherwise known only from Central Texas, northern trans-Pecos Texas, and northwestward through New Mexico.

Selinocarpus angustifolius Torr. Bot. Mex. Bound. 170, t. 47 (1859).

Coahuila: 2 mi. west of Sacramento, road to Cuatro Cienegas, rocky hillside, erect shrub $3 \mathrm{ft}$. tall, Johnston 7100; $4 \mathrm{mi}$. west of Cuatro Cienegas, mouth of canyon, Johnston 7159; hills near Mesillas, shrub $1 \mathrm{ft}$. tall, Sept. 23, 1848, Gregg 535; road to Torreon, $55 \mathrm{mi}$. west of Saltillo (23 mi. east of Paila), steep rocky sandstone slope, plant strict, erect, 6-24 inches tall, Johnston 7690; 14 mi. east of Paila, Shreve $\mathcal{E}^{\circ}$ Tinkham 9900; Picachos Colorados, rocky soil at base of cliffs, Johnston $\mathcal{E}$ Muller 136; northwestern foothills of Sierra Cruces, limy mine-dump, shrubby, up to $3 \mathrm{ft}$. tall. Johnston $\mathcal{E}$ Muller 1059; Cañon Tinaja Blanca, Sierra Cruces, dry hillsides and cliffs, 1-3 ft. tall, Stewart 579, Johnston $\mathcal{E}$ Muller 277; vicinity of Santa Elena, sides of arroyos, Stewart 252, 281; limestone ledges on very arid hills near La Pistola, east side of Llano de Guaje, shrub 1-2 ft. tall, Johnston \& Muller 769; canyon at San Antonio de los Alamos, crevices of basalt and at base of tuff cliffs, 1-4 ft. tall, Johnston 8269, Johnston \& Muller 931; $14 \mathrm{~km}$. southeast of Rancho Alegre on road south to Valle Acatita, gypsum slopes, Stewart 2682; Rancho Las Uvas, shales on slopes, $5 \mathrm{dm}$. tall, Stewart 2716; San Lorenzo de la Laguna, 1880, Palmer 1119; Viesca, Feb. 1905, Purpus 1054. Chinuahua: Presidio del Norte [Ojinaga], Bigelow, Parry (isotypes).

Known only from our area and adjacent Texas; ranging north in Texas to the Chinati Mts., Presidio Co., and central Brewster Co. A shrub 1-3 $\mathrm{ft}$. tall with slender usually rather strict branches, growing in dry welldrained places on hillsides and on and about cliffs and banks. Though centering in a calcareous region, it shows no marked soil preferences. I have found it on basalt, volcanic tuff, igneous intrusives, limestones, caliche, and gypsum. It is rarely common. It fruits freely but most of the fruit appears to develop from cleistogamic flowers. The species usually has narrow lanceolate or linear-lanceolate leaves. There are, however, three 
collections from eastern Coahuila (Gregg 535, Johnston 7159, and Shreve $\mathcal{E}$ Tinkham 9900) which have oblong or oblong-elliptic, perhaps thinner, leaf-blades that are folded and have crisped-undulate margins.

Selinocarpus parvifolius (Torr.) Standl. Contr. U. S. Nat. Herb. 12: 388 (1909).

Selinocarpus diffusus var. parvifolius Torr. Bot. Mex. Bound. 168 (1859).

Chinuahua: $10 \mathrm{mi}$. south of Ojinaga, base of low hills on outwash from gypseous and saline clays and shales, globose bush 1-2 ft. tall, Johnston \& Muller 12, 1446; Presidio del Norte [Ojinaga], August, Bigelow.

Known only from the valley of the Rio Grande in Presidio and Brewster Counties, Texas, and in adjoining Chihuahua. The type was collected by Parry in "Cañons of the Rio Grande," presumably those between Ojinaga and the Big Bend. The species is probably a gypsophile and appears to be confined to areas of Upper Cretaceous shales and clays.

Selinocarpus Palmeri Hemsl. Biol. Centr. Am. Bot. 3: 6. t. 70 (1882).

CoAhuila: San Lorenzo de la Laguna, flowers bright pink with whitish base, May 1880, Palmer 1118 (ISOTYPE).

Known only from the type collection. Nothing is recorded regarding the growth habit of this plant. The specimens suggest that it is a bush as large as or even larger than its relative, S. Purpusianus, but much more loosely branched. Like its relative it is probably a gypsophile.

Selinocarpus Purpusianus Heimerl, Oesterr. Bot. Zeits. 63: 353 (1913).

Coahulla: Near Mohovano on road $16 \mathrm{mi}$. south of Laguna del Rey, confined to gypsum flat, frequent, rounded gray intricate bush 1-3 ft. tall, fl. yellowish, Johnston 7807 ; Laguna del Rey, fl. yellow, Stewart 2652; Sierra del Rey, June 1910, Purpus 4505 (ISOTYPE) ; valley between La Vibora and Matrimonio Viejo, confined to gypsum-beds, frequent bush 1-3 ft. tall, Johnston 9337.

This gypsophilous species is known only from the collections cited. It is a grayish bush 1-3 ft. tall with gnarled woody branches and abundant dichotomous intricately interlocked twigs. The perianth has a bright yellow limb.

Selinocarpus Marshii sp. nov.

Frutex lignosus intricate et dichotome ramosissimus; ramulis foliatis simplice vel sparse et dichotome ramosis $2-4 \mathrm{~cm}$. longis pilis minutis abundantis cinereis retrorsis obtectis; ramulis vetustioribus glabrescentibus sub lente multistriatis; foliis oppositis $9-13 \mathrm{~mm}$. longis ca. $2 \mathrm{~mm}$. latis, lanceolatis vel oblanceolatis, costatis sed enervatis, carnosulis bifacialibus viridibus, pilis pallidis retrorsis et pilis inconspicuis glanduliferis vestitis, basi gradatim attenuatis, apice acutis; floribus in axillis foliorum solitariis; pedicellis $0.5-2 \mathrm{~mm}$. longis paullo infra apicem bracteis duobus ad $2 \mathrm{~mm}$. longis oppositis lanceolatis inconspicuis gestis; perianthio $3-4 \mathrm{~cm}$. longo elongate infundibuliformi extus cinereo pilis minutis pallidis reflexis vestito, parte ovariali ad $5 \mathrm{~mm}$. longo 5 -angulato, deinde sursum in tubo ca. $1 \mathrm{~mm}$. crasso et $2 \mathrm{~cm}$. longo transmutato, apice tubi (in alabastro) sursum in fauces 0.5-0.7 mm. longas et ca. $3 \mathrm{~mm}$. diametro et lobos ca. $0.8 \mathrm{~mm}$. longos ampliato; anthocarpio 4-alato, corpore $9 \mathrm{~mm}$. longo quadrangulari, faciebus ad $2 \mathrm{~mm}$. latis bisulcatis sparse et retrorse strigulosis, alis ad $4 \mathrm{~mm}$. latis.

Coahulla: Hermanas, April 20, 1937, Marsh 1579 (Type, Gray Herb.).

A close relative of $S$. Purpusianus, from which it differs in having the 
branchlets, leaves, and perianth clothed in a gray indument of abundant minute appressed flattened white hairs, its leaf-bearing branchlets only very obscurely sulcate, and its perianth without glandular hairs. The type collection lacks data on habit and habitat and has flowers in mature bud but lacks perianths at anthesis. The species, however, probably agrees with S. Purpusianus in habit of growth, soil preference, and in the size and shape of perianth. That latter species, however, differs from S. Marshii in having the leaf-bearing branchlets very strongly sulcate and roughened with stipitate glands and some scattered stiffish erect hairs. Its green, evidently more succulent leaves are also roughened with stipitate glands. The two species differ strikingly in abundance and quality of indument.

Allionia incarnata L. Syst. ed. 10. 890 (1759).

Wedeliella incarnata (L.) Cockerell, Torreya 9: 167 (1909).

Vernacular names: Yerba de la Hormiga; Yerba de la Mosca; Yerba del Hormigero.

Coahulla: Allende, Marsh 2234; Cañon de Cienegas, Cuatro Cienegas, fl. red, White 1890; Monclova, Marsh 1825; desert near Rancho Santa Teresa, south of Castaños, Wynd $\mathcal{E}$ Mueller 189; between Hipólito and Sacramento, dry arroyos, Wynd $\mathcal{E}$ Mueller 72; 2 mi. west of Saltillo, road tc Torreon, fl. reddish lavender, White 1666; Saltillo, waste places and bottom lands, prostrate, fl. damask-colored, 1898, Palmer 81; Saltillo, scarce, fl. purplish, July 16, 1848, Gregg 251; Sierra del Carmen, Sept. 2, 1936, Marsh 735, 867; $7 \mathrm{~km}$. north of Agritos, east of Sierra del Pino, prostrate, dry flats, fl. orchid, Stewart 1276; $25 \mathrm{~km}$. west of San Guillermo (northeast of Sierra del Pino), common on flats, fl. orchid, Stewart 1772, $6 \mathrm{~km}$. east of El Tule, southern Sierra Hechiceros, sandy arroyo, fl. orchid, Stewart 486;9 km. north of San Rafael, road to Castillon, hillsides, spreading, fl. lavender, Stewart 420; vicinity of Santa Elena, arroyos and hillsides, Stewart 258, 603; Tinaja Blanca, Sierra Cruces, creeping, arroyos and hillsides, abundant, fl. purple, Stewart 341; $5 \mathrm{mi}$. west of El Oro, road to Guimbalete, White 1992; near Noria San Juan, southeast of Laguna del Rey, saline flats, fl. purplish, Stewart 3011; flats west of Las Uvas, Valle Acatita, prostrate, fl. purple, Stewart 2694, 2709; $13 \mathrm{~km}$. South of Rancho Acatita, sandy plain, prostrate, fl. purplish, Stewart 2986; Cañon del Agua Grande, west of Las Delicias, dry slopes, fl. purple, Stewart 2793. Chinuanua: Chihuahua, about mesas and arroyos, prostrate, fl. rosecolored, 1908, Palmer 194; Chihuahua, 1935, LeSueur 123; 25 mi. south of Chihuahua, 1936, LeSueur; $12 \mathrm{mi}$. south of Camargo, White 2191; northeast end of Sierra Diablo, rocky arroyo high in canyon, prostrate, fl. orchid, Stewart 993.

Southern California to trans-Pecos and southern Texas and south into Durango, Zacatecas, and middle-eastern Tamaulipas; also in western South America. A trailing herb which is widespread and frequently common in open places on silty flats and valley slopes and in rocky soils on hillsides and in arroyos. As is so common among the herbaceous members of the Nyctaginaceae, this plant is extremely variable in indument. This and other variations of the species have been discussed in detail by Heimerl, Repert. Sp. Nov. 31:91-98 (1932). The fruit has firm usually incurved wing-margins which are either entire or coarsely and broadly toothed. Except for a few plants from the Big Bend and the lower Rio Grande Valley, which have more spreading and more deeply toothed margins on the fruit than common in A. incarnata, I have seen no plants whose fruit could be considered transitional between A. incarnata and A. Choisyi. Standley reports the species from hills about Tlahualilo, Durango (Pittier 486), 
and Heimerl lists a collection from between Mapimi and Ojuelo, Durango (Endlich 255).

Allionia Choisyi Standl. Field Mus. Publ. Bot. 8:310 (1931).

Allionia incarnata L. var. glabra Choisy in DC. Prodr. $13^{2}: 435$ (1849).

Wedeliella glabra (Choisy) Cockerell, Torreya 9:167 (1909).

Allionia incarnata f. multiserrata Heimerl in Urban, Symb. Ant. 7: 212 (1912).

Vernacular name: Yerba de la Hormiga.

Coahulla: Monclova, Marsh 1655; Perros Bravos, fl. purple, frequent, Sept. 20, 1848, Gregg 466. Chinuahua: $25 \mathrm{~km}$. northwest of Jaco, prostrate on silty flats, fl. orchid, fairly common, Stewart 680; $4 \mathrm{~km}$. northeast of Santa Fe, common on flats, prostrate, fl. purplish, Stewart 2596. ZaCateCas: Cedros, garden, 1908, Kirkwood 115.

Eastern Arizona to trans-Pecos and southern Texas and south through Coahuila, Nuevo Leon, Tamaulipas, and San Luis Potosi into central and southern Mexico; also in the West Indies. Distinguished from $A$. incarnata by having the margin of the fruit pectinately lobed. Each margin is divided into 5-7 slender linear-subulate ascending or more commonly incurving lobes. In $A$. incarnata the margin is subentire or is coarsely and frequently irregularly dentate with $2-6$ broadly triangular teeth. The forms of $A$. Choisyi found in the United States are usually glabrous and annual and have the medial crest on the outer face of the fruit bearing sessile or subsessile glands. In eastern Mexico the plants are mostly perennial, frequently hairy and glandular, and in central Mexico and the West Indies they may have the medial keels toothed or even with very slender appendages half to nearly as long as the lobes of the lateral margins. The type of A. Choisyi Standl. and A. incarnata var. glabra Choisy, upon which it is based, came from near Mexico City. In our area some plants are annual, others are perennial, and some are nearly glabrous and others show various amounts of viscid indument. The species appears to be almost as variable as $A$. incarnata.

Nyctaginia capitata Choisy in DC. Prodr. $13^{2}: 429$ (1849).

Vernacular NAMES: Immortal; (root) Yerba Blanca.

Coahuila: Sierra del Carmen, Sept. 13, 1936, Marsh 902; Allende, 1939, Marsh 1786; Sabinas, 1902, Nelson 6761; 2 mi. northwest of Frontera, road to Natadores, silty desert plain, Johnston 7175 ; Cuatro Cienegas, 1939, Marsh 2019; flats of La Vega, 15 mi. southeast of Cuatro Cienegas, Schroeder 176; desert near Rancho Santa Teresa, south of Castaños, Wynd \& Mueller 179; Saltillo, frequent, fl. bright red, July 16, 1848, Gregg 264; Saltillo, clay soil, plains and waste places, fl. vermilion, 1898, Palmer 202; Saltillo, 1930, Fisher 30033; Cienega Grande, fl. scarlet, May 18, 1847, Gregg; Valle de los Guajes, $25 \mathrm{~km}$. south of Rancho Buena Vista, grassy flat, Stewart $1328 ; 10 \mathrm{~km}$. north of Agritos, silty flat, fl. red, Stewart 1278; $20 \mathrm{~km}$. south of Castillon, along arroyo, fl. red, Stewart $427 ; 8 \mathrm{~km}$. east of La Palma, valley north of Sierra Cruces, tobosa flat, fl. red, Stewart $656 ; 5 \mathrm{mi}$. northwest of Zenzontle, flat, corolla dark red, filaments magenta, Johnston $\mathcal{E}$ Muller 973 ; silty plain $2 \mathrm{mi}$. east of Bufido, oily and succulent, Johnston \& Muller 854; valley west of Bufido, silty soil, Johnston \& Muller 845; northwest end of Sierra Planchada, tobosa flat, fl. red, Stewart 1012; Jimulco, May 16, 1885, Pringle. Chrmuanua: Near Trinidad, flats, fl. red, Stewart 2592, 2593; 25 mi. south of Chihuahua, 1936, LeSueur; Ojo El Gallego, between Chihuahua and El Paso, 1846, Wislizenus (St. Louis). Durango: Mapimi, edge of cornfield, 1898, Palmer 545.

Trans-Pecos Texas and southeastern New Mexico to southern Texas and south into our area and adjacent Nuevo Leon. Reaching its southern limit 
in central Durango. A plant with viscid-glandular rather succulent herbage and umbellate clusters of trumpet-shaped red or vermilion flowers, characteristic of clay valley soils and particularly of flats where water temporarily accumulates after storms. The stems are prostrate or trailing, commonly nearly a meter long, and arise from a coarse fleshy deeply descending root. Palmer reports that the dried root, because of its color called Yerba Blanca, is sold in the market at Saltillo and is said to be a popular remedy for stomach-ache. In some localities the plants appear to be prevailingly cleistogamic. Such plants have short stems, less than a decimeter in length, and some of them have only a basal rosette of leaves and the dense cluster of cleistogamic flowers borne at the level of the soil or even partially covered by it.

Acleisanthes longiflora Gray, Am. Jour. Sci. II. 15: 261 (1853).

Acleisanthes longiflora subsp. hirtella Standl. Contr. U. S. Nat. Herb. 12: 371 (1909).

Acleisanthes longiflora var. hirtella Standl. ex Heimerl, Notizbl. Bot. Gart. Berlin 11: 459 (1932).

Vernacular names: Yerba Santa; Yerba de la rabia; Platiada; Trompetilla.

Coahuila: Allende, 1939, Marsh 1802; Santa Anna Canyon, 1936, Marsh 536; Puerto San Lazaro, rocky slopes, Wynd \& Mueller 158; Perros Bravos, fl. white, Sept. 20, 1848, Gregg 463 (isotype of var. hirtella); Saltillo, fl. white, night bloomer, 1898, Palmer 181; battlefield near Buena Vista, frequent, May 19, 1848, Gregg 88; Cañon Ybarra, Sierra del Pino, dry hillside, fl. white, Stewart 1847; Sierra del Pino, limestone ledges at mouth of south canyon, fl. white, opening at dusk, Johnston $\mathcal{E}$ Muller 729; valley northeast of Tanque Armendais, stony slope, Johnston \& Muller 374; vicinity of Santa Elena, fl. white, Stewart 233, 244, 369, 1927; Cañon Tinaja Blanca, Sierra Cruces, hillside, fl. white, Stewart 589; Bolson de los Lipanes, between El Almagre and Cerros de Leja, silty plain, fl. white, Johnston \& Muller 1250; La Botica, Valle Delicias, flats, fl. white, Stewart 2847; Parras, 1880, Palmer 1116; Jimulco, May 12, 1885, Pringle 122. Chinuahua: Ojinaga, edge of field, Shreve 8103; Sierra San Carlos, road to mines, silty soil in canyon, Johnston \& Muller 56; north of El Pino, about $10 \mathrm{~km}$. southeast of Sierra Rica, rocky slope, fl. white, Stewart 2418; Cantarrecio, sands, Oct. 1852, Thurber 808; Aldama, prostrate, covering quite a space on mesquite bottoms, fl. white with a violet shading to tube, 1908, Palmer 243; rocky hills near Chihuahua, June 5, 1885, Pringle 101.

Central and southern Texas west into trans-Pecos Texas and southeastern New Mexico and south into northeastern Mexico; also in Arizona and southeastern California. A prostrate or very laxly decumbent plant of silty or rocky soils, frequently forming mats up to a meter in diameter. It appears to be confined to calcareous soils and is particularly common on loose rocky soils, such as talus, about the base of limestone mountains. The unusually slender and elongate white flowers, with tubes $10-15 \mathrm{~cm}$. long and an abruptly spreading lobe about $15 \mathrm{~mm}$. wide, stand erect from the prostrate herbage. The sight of a plant in full flower, with a score or more of these slender graceful elongate white trumpets arising from the gray carpet of the herbage, is a pleasure which can be enjoyed only for a brief period at dusk or for a few hours during an overcast morning, for the flowers usually open at dusk and close at or before sunrise. During the day the tubes of the closed flowers stand like quills or, withering, arch over or lie across the herbage. The plant has a very coarse fleshy taproot which becomes somewhat enlarged a decimeter or so below the surface of 
the soil. Gregg reports that a decoction of the root was used for cholera, fevers, etc. The species commonly has foliage which is smooth and glabrous, or practically so. Rarely it is roughened by stiffish hairs. This minor form was described as subsp. hirtella. Heimerl has reported collections of it from the Sierra de la Paila (Endlich 844).

Acleisanthes crassifolia Gray, Am. Jour. Sci. II. 15: 260 (1853).

Coahuila: Muzquiz, 1938, Marsh 1105.

Known otherwise only from Val Verde County, Texas; the type was collected near Del Rio. The cited collection has mature fruit developed from cleistogamic flowers.

Acleisanthes acutifolia Standl. Contr. U. S. Nat. Herb. 12:370 (1909).

Coahuila: Saltillo, base of stony ridge, fl. cream-colored, 1898, Palmer 282; Carneros Pass, fl. pale lilac, Sept. 9, 1889, Pringle 2843; Sierra del Pino, mouth of south canyon, gravelly bench at base of limestone slope, fl. white, Johnston $\mathcal{E}$ Muller 728; west base of Picacho del Fuste, rocky flats, prostrate, fl. white, Johnston 8416; near Aguaje Pajarito, west end of Sierra Fragua, decumbent, fl. white with yellowish ribs, Johnston 8791; south base of Picacho San José, sunny rocky terrace, fl. fleshcolored, Johnston \& Muller 819; Carrizo, south base of Sierra Cruz, dry open hillside. fl. white, Stewart 2168; Rancho Parritas, east side Valle Acatita, gypsum mesa, fl. white, Stewart 2765; Sierra Parras, Oct. 1910, Purpus 4753. Chinuahua: Sierra Santa Eulalia, Aug. 25, 1885, Pringle 671. ZaCATeCAS: Cardona, rocky hillside, decumbent, fl. whitish, Johnston 7376 .

Ranging from our area north into trans-Pecos Texas (Brewster and Pecos Counties). A perennial, with numerous leafy prostrate or laxly ascending stems 1-2 dm. long. It appears to be confined to rocky limestone soil and is not common.

Acleisanthes nana sp. nov.

Planta parva perennis humilis grisea e radice palari crassa profunda oriens; caulibus pluribus decumbentibus vel ascendentibus foliosis $2-5 \mathrm{~cm}$. longis gracilibus breviter ramosis pilis hispidulis et glanduliferis et pilis albidis appressis plus minusve ornatis; foliis oppositis crassiusculis inconspicue et sparse nervatis; foliis infimis mox deciduis modice majoribus obtusis plus minusve glabris conspicue petiolatis; foliis caulinis numerosis quam internodiis saepe duplo longioribus, setis subulatis rigidis erectis glanduliferis conspicue obsitis, pilis albidis appressis plus minusve ornatis, lamina lanceolata $8-14 \mathrm{~mm}$. longa $3-7 \mathrm{~mm}$. lata, infra medium latiore, deinde basim versus in petiolum $2-4 \mathrm{~mm}$. longum contracta, apice acuta, margine plus minusve crispata; floribus in axillis foliorum subsessilibus; bracteis involucralibus 3 lanceolatis $2-3 \mathrm{~mm}$. longis quam anthocarpio duplo brevioribus; perianthio infundibuliformi $12-15 \mathrm{~mm}$. longo extus hispidulo-puberulente, limbo ad $13 \mathrm{~mm}$. diametro, staminibus 5 exsertis: anthocarpio 5-6 mm. longo $1-1.5 \mathrm{~mm}$. crasso prismatico glandulari-puberulente, lateraliter sulcis duobus approximatis lineatis profundis basim versus ornato, sub apice abrupte contracto, apice supra costas principales glandulas magnas hemisphaericas gerente.

Coahuila: Fraile, valley, July 10, 1941, Stanford et al. 201. SAn Luis Potost: Los Charcos, May 15, 1891, Pringle 5081 (Ty PE, Gray Herb.).

A very well-marked species related to $A$. Wrightii and $A$. acutifolia, from which it is readily distinguished by its dwarf habit, small glandular hispid 
lanceolate leaves, small flowers, short involucral bracts, and small prismatic glandular-puberulent 10-ribbed anthocarp. The anthocarp is distinctive. It is slightly the thickest above the middle, several times longer than broad, and prismatic in general form. Down each side there is a pair of parallel grooves which obviously deepen and broaden towards the base and apex. These grooves evidently delimit five lateral ribs which have been crowded and narrowed by the lateral outgrowth and expansion of the five broad principal ribs forming the angles of the fruit. This condition is different from that in $A$. Wrightii and A. acutifolia, in which the lateral ribs are not evident, being apparently completely covered by the overgrowth of the principal ribs. At the summit of the fruit in A. nana the principal ribs are replaced by five hemispherical glands which do not protrude above the level of the ribs.

The species is known only from Fraile and Charcos. No information is available as to the exact habitat selected by the plant. However, judging from the behavior of other rare plants known from these two general localities, I suspect that A. nana may be gypsophilous.

Boerhavia linearifolia Gray, Am. Jour. Sci. II. 15: 322 (1853).

Boerhavia linearifolia var. glabrata Gray, Am. Jour. Sci. II. 15: 322 (1853).

Boerhavia tenuifolia Gray ex Coult. Contr. U. S. Nat. Herb. 2:355 (1894).

Boerhavia linearifolia subsp. glandulosa Standl. Contr. U. S. Nat. Herb. 12:387 (1909).

Boerhavia Lindheimeri Standl. No. Am. Fl. 21: 208 (1918).

Coahuila: Rancho Agua Dulce, lower slopes of Sierra San Manuel, Wynd $\mathcal{E}$ Mueller 356; Puerto Santa Anna, July 21, 1936, Marsh 941; mountains 24 mi. northeast of Monclova, 1880, Palmer 1122; Sierra de la Paila, Oct. 1910, Purpus 4958; Saltillo, stony hill-slope under bushes, fl. damask-color, 1898, Palmer 155; Saltillo, highlands, scarce, fl. purple, June 2, 1848, Gregg 110; Buena Vista, south of Saltillo, frequent, fl. purplish red, July 24, 1848, Gregg 281; Carneros area, 1880, Palmer 1121; slopes of Sierra del Carmen $10 \mathrm{~km}$. northeast of Hac. Encantada, arroyo banks, fairly common, Stewart 1563; Mesa Grande, $40 \mathrm{~km}$. northwest of Hac. Encantada, open hillside, fairly common, fl. purple, Stewart 1610; base of Sierra Guajes $7 \mathrm{~km}$. east of Rancho Buena Vista, limestone hillside, fairly common, fl. orchid, Stewart 1478; high mesa $12 \mathrm{~km}$. northwest of Rancho Buena Vista, hillside, fl. purple, Stewart 1431; $20 \mathrm{~km}$. northwest of Puerto del Aire, grassy hills, fl. purple, Stewart 1284; Sierra del Pino, ridge west of La Noria, on ledges, prostrate, fl. magenta, Johnston \& Muller 620; Sierra Madera, Cañon Pajarito, dry rocky arroyo, fl. lavender, Muller 3151; Sierra Madera, Cañon Charretera, rocky open flats, stems spreading, fl. pink, Johnston 9138; near Santa Elena, eastern foothills of Sierra Cruces, along arroyos and on limestone slopes, prostrate or ascending, Stewart 262, Johnston \& Muller 212; Cañon Tinaja Blanca, Sierra Cruces, dry open hillsides, fl. purple, Stewart 593; La Botica, Valle Delicias, in arroyos, ascending, fl. purple, Stewart 2884. Chinuanua: Sierra San Carlos, road to mines, rocky ridge crest, Johnston \& Muller 66;1 km. southeast of Rancho Madera, southeast base of Sierra Rica, dry arroyo, ascending, fl. purple, Stewart 2442; south end of Sierra Seca, $5 \mathrm{~km}$. south of San José del Progreso, dry rocky slope, frequent, ascending, fl. purple, Stewart 2306.

Central and trans-Pecos Texas and adjoining New Mexico south into our area. A plant of hillsides and stabilized alluvial terraces in limestone areas. It has a strong deep woody tap-root and usually very numerous prostrate or ascending slender wiry stems $1-2 \mathrm{dm}$. long. Its narrowly to broadly lanceolate, frequently revolute-margined leaves, usually $2-3 \mathrm{~cm}$. long, 
readily distinguish this species. As with other congeners it is variable in indument, being smooth and glabrous or minutely glandular and more or less hispidulous or even shaggy-hispid on the stems. Plants varying widely in indument and in leaf-size and -shape may usually be found in any locality. The type of the species, the only specimen upon which Gray wrote "Boerhaavia linearifolia n. sp.," is that part of Wright 608 which was collected on a "high rocky limestone prairie" between Turkey and Elm creeks, in eastern Kinney Co., Texas. It is a form with the leaves hispid and the stems glandular and shaggy-hispid. The type of var. glabrata, also part of Wright 608, was collected in the "pebbly bed of a small creek beyond Zacate Creek," i.e. in eastern Val Verde Co., Texas. It consists of two branches, one completely glabrous and smooth, the other with scattered minute glands and (towards the base) sparsely minute-hispidulous.

Boerhavia anisophylla Torr. Bot. Mex. Bound. 171 (1859).

Boerhavia Palmeri Wats. Proc. Am. Acad. 18: 142 (1883).

Boerhavia anisophylla f. polytricha Heimerl, Repert. Sp. Nov. 12: 220 (1913).

Vernaculab name: Yerba de la mosca.

Coahuila: Hills near Mesillas, frequent, 1-2 ft., fl. purple, Sept. 23, 1848, Gregg 533; Saltillo, 1880, Palmer 1120 (type of B. Palmeri); Saltillo, base of stony hills and in ravines, fl. crimson-purple, 1898, Palmer 156;2 mi. west of Saltillo, road to Torreon, fl. pinkish, White 1683; southern foothills of Sierra Hechiceros, $6 \mathrm{~km}$. east of El Tule, fairly common on hillsides, fl. orchid, Stewart 467; 9 mi. south of El Tule, south base of Sierra Hechiceros, exposed gravelly ridge, stems erect or ascending, fl. purple, Johnston \& M.uller 1373; Tanque Jerico, with Hechtia on limestone hillside, Johnston 8336; Cerro de Cypriano, crevices of rocks, June 1910, Purpus 4544. Chinuahua: Chihuahua, 1935, LeSueur 37; Sierra Santa Eulalia, limestone hills, Aug. 12, 1885, Pringle 685; Los Reyes, about $8 \mathrm{mi}$. south of Jimenez, fl. reddish purple, White 2114. Durango: Yerbanis, Shreve 9135.

Brewster County, Texas, south in Chihuahua, Coahuila, and Tamaulipas to San Luis Potosi and Durango. Apparently confined to calcareous rocks. A perennial with a thick woody tap-root. The stems are few, rather coarse and stiff and sparsely branched. The plant is decumbent and leafy below the middle and above erect and strongly ascending. The type was collected at the "Entrance of the Grand Cañon of the Rio Grande" and is an unusual form with the stems and leaves practically glabrous. Most collections of the species have the stems, and frequently the leaves, densely and minutely glandular, and commonly also hispidulous. Coarse hairs, in varying abundance, are frequently present on the basal stem-internodes. The forma polytricha, representing the common form in our area, is based upon Endlich $175 b$ from near Yerbanis, Durango.

Boerhavia gracillima Heimerl, Bot. Jahrb. 11: 86 (1889).

Boerhavia anisophylla var. paniculata Coult. Contr. U. S. Nat. Herb. 2: 356 (1894).

Boerhavia organensis Standl. Contr. U. S. Nat. Herb. 12: 385 (1909).

Boerhavia gracillima subsp. decalvata Standl. Contr. U. S. Nat. Herb. 12: 386 (1909).

Coahuila: Sierra del Carmen, Aug. 22, 1936, Marsh 577; Santa Anna Canyon, 1936, Marsh 552; Puerto San Lazaro, rocky slopes, Wynd \& Mueller 125; Picacho Noche Buena, basalt ledges, prostrate, widely spreading, fl. red, Johnston \& Muller 178; Cañon Indio Felipe, Sierra Hechiceros, cliffs, fl. purple, Stewart 148; Cañon Tinaja Blanca, Sierra Cruces, bed of sandy arroyo, prostrate, fl. red, Stewart $627 ; 8 \mathrm{~km}$. northeast of Santa Elena, dry limestone hillside, prostrate, fl. red, Stewart 1123; near 
San José, southeast of Sierra Cruces, about cliffs of limy conglomerate, prostrate, stems becoming $12 \mathrm{dm}$. long, fl. reddish, Johnston $\mathcal{E}$ Muller 999. Chrhuahua: Sierra San Carlos, road to mine, canyon-bottom, prostrate, fl. red, Johnston $\mathcal{E}$ Muller 51; Cañon Madera, Sierra Rica, dry rocky arroyo, fl. reddish, Stewart 2526; $10 \mathrm{~km}$. north of Escobillas, open rocky slope, prostrate, fl. reddish, Stewart 2378; 3 mi. south of Pirámide, gravelly terrace along arroyo, prostrate, Johnston 8109; hills southeast of Chihuahua, Aug. 15, 1885, Pringle 665; Chihuahua, in arroyos, fl. maroon, 1908, Palmer 199.

Trans-Pecos Texas (Brewster Co. west) to Arizona and south to southern Mexico. A perennial with a strong woody deep tap-root. The stems become 10-15 dm. long. A plant may cover an area a meter or more in diameter, its repeatedly branched slender branches and branchlets bearing myriads of small wine-colored flowers. The species appears to be widely distributed but is only locally common, and then seemingly in disturbed rocky soils. Because of its lack of glandularity and the very elongate slender pedicels, the plant seems cleaner and more openly branched than usual in this genus.

Boerhavia coccinea Mill. Gard. Dict. ed. 8. no. 4 (1768).

Boerhavia hirsuta Jacq. Hort. Bot. Vind. 1:3.t. 7 (1770); L. Mant. 2: 170 (1771);

Willd. Phytogr. 1: 1 (1794), Sp. Pl. 1: 20 (1797).

Boerhavia caribaea Jacq. Obs. Bot. 4: 5. t. 84 (1771).

Boerhavia polymorpha Rich. Act. Soc. Hist. Nat. Paris 1: 185 (1792); Heimerl, Ann. Cons. et Jard. Bot. Genève 5 : 188 (1901).

Boerhavia viscosa Lag. \& Rodr. Anal. Cienc. Nat. Hist. 4: 256 (1801).

Boerhavia ramulosa Jones, Contr. W. Bot. 10: 40 (1902).

Boerhavia ixodes Standl. Contr. U. S. Nat. Herb. 13: 423 (1911).

Conhulla: Monclova, 1939, Marsh 1727; San Antonio de los Alamos, shaded gravelly canyon-floor, stems widely spreading, Johnston $\mathcal{E}$ Muller 882; Cañon Tinaja Blanca, Sierra Cruces, banks of arroyo, not common, fl. dark red, Stewart 1136; north end of Bolson de los Lipanes, between El Almagre and Cerros de Leja, margin of mogote on plain, prostrate-spreading, Johnston $\mathcal{E}$ Muller 1254; Rancho La Botica, Valle Delicias, common in arroyos, prostrate, fl. purplish, Stewart 2881; Horizonte, 1937, Wynd 775; Torreon, ditch-bank, very widely spreading, fl. crimson, 1898, Palmer 487. Chinuahua: Rancho El Pino, $10 \mathrm{~km}$. southeast of Sierra Rica, rocky slope, fl. reddish, Stewart 2387; $8 \mathrm{~km}$. south of Rancho Encinillas, sandy flat, prostrate, fl. red, Stewart $711 ; 7 \mathrm{mi}$. east of Victoria, sprawling in bushes on arroyo-bank, Stewart $\mathcal{E}$ Johnston 2001; Chihuahua, stony arroyos, not common, fl. crimson, 1908, Palmer 193; Presa de Chihuahua, 1936, LeSueur 617; valley near San Pablo, fl. red, April 29, 1847, Gregg; $3 \mathrm{mi}$. north of San Lucas on road to Chihuahua, fl. red, White 2319; $3 \mathrm{mi}$. west of Camargo, fl. dark red, White 2273. ZaCatecas: Concepcion del Oro, widely spreading, fl. maroon, 1904, Palmer 290.

Florida to southeastern California and south in the warmer parts of America. For the present plant Standley, No. Am. Fl. 21: 206 (1918), took up and gave currency to the name B. caribaea Jacq. (1771). Unfortunately, however, that name undoubtedly has earlier valid synonyms in B. coccinea Miller (1768) and B. hirsuta Jacq. (1770). If our American plant is to be distinguished from the Old World $B$. diffusa L. it must be called B. coccinea Miller. By some mischance Standley applied Miller's name to another tropical species which previously had been generally known as B. paniculata Rich. (1792). The name "B. paniculata" of L. C. Richard, however, is antedated by $B$. paniculata Lam. (1791) and the 
tropical species known as " $B$. paniculata" appears to have its earliest name in B. adscendens Willd. (1797), cf. Heimerl, Bot. Jahrb. 21: 619 (1896).

This is a perennial species with elongate prostrate or widely spreading stems. Like most members of the group it is variable as to indument, being glandular throughout or only towards the base, and having the stems with or without conspicuous elongate hairs. Its dense umbellate clusters of glandular fruits readily distinguish the species from $B$. gracillima.

Boerhavia erecta L. Sp. Pl. 3 (1753).

CoAhuila: $2 \mathrm{~km}$. west of Santa Elena, foothills of the Sierra Cruces, flats, not common, erect, 5-10 dm. tall, fl. light pink, Stewart 837; Bolson de los Lipanes, between El Almagre and Cerros de Leja, margin of mogote on plain, erect with ascending branches, Johnston $\mathcal{E}$ Muller 1255. Chinuahua: Pass $10 \mathrm{mi}$. south of Mula, alluvial terrace, erect, Johnston 8046; 13 mi. west of Chihuahua, road to Santa Isabel, fl. pink, White 2459; 8 mi. north of San Lucas, road to Chihuahua, fl. white, White 2322; 12 mi. south of Camargo, fl. pinkish, White 2205; 31 mi. southeast of Jimenez, abundant on grassy slopes, fl. pink, Muller 3328; Cañon del Coyote, southern end of Sierra Diablo, frequent in dry arroyos, fl. white, Stewart 2615.

Widely distributed in the warmer parts of America, extending north to southern Arizona and New Mexico and along the coastal plain through eastern Texas and Florida north to South Carolina. An upright annual herb becoming 5-10 dm. tall. The plant has one or a very few erect or nearly erect stems which are ascendingly branched above. Standley, Contr. U. S. Nat. Herb. 13:427 (1911), cites a collection (Pittier 487) from "barren hills about Tlahualilo," Durango.

Boerhavia intermedia Jones, Contr. W. Bot. 10: 41. t. 16 (1902).

Boerhavia universitatis Standl. Contr. U. S. Nat. Herb. 12: 380 (1909).

Boerhavia erecta var. intermedia Kearney \& Peebles, Jour. Wash. Acad. 29:475 (1939).

CoAhuila: $12 \mathrm{mi}$. north of Monclova, silty valley soil in mesquite thicket, Johnston 7189; Monclova, 1880, Palmer 1123; $2 \mathrm{~km}$. west of Santa Elena, foothills of the Sierra Cruces, flats, Stewart $837 \mathrm{~A}$; Zenzontle, stony sunny slope, prostrate, Johnston $\mathcal{E}$ Muller 965;2-3 mi. north of San Antonio de los Alamos, gravelly plain, plant spreading, Johnston 8231; San Antonio de los Alamos, dry gravelly slope below tuff cliffs, stems ascending, Johnston $\mathcal{E}$ Muller 888; Cañon del Agua Chica, west of Las Delicias, common on flats, stems ascending, fl. white, Stewart 2832; Torreon, in shade of mesquites on plain, 1898, Palmer 468. Chinuahua: Pass $10 \mathrm{mi}$. south of Mula, alluvial terrace, diffuse, Johnston 8045 ; low ridge a mile southwest of Mesteñas, rocky slope, not common, prostrate, Stewart \& Johnston 2025; Meoqui, 1936-37, LeSueur; 8 mi. north of San Lucas, road to Chihuahua, fl. pink, White 2320; 15 mi. west of Las Delicias, road to San Lucas, fl. pink, White 2296. Durango: Cerro de San Ignacio, July 1910, Purpus 4619.

Trans-Pecos Texas to southeastern California and south into northern Mexico. Reaching its southern limit in our area. The species is probably most closely related to $B$. erecta, but differs in size, habit, inflorescence, and distribution. It has been collected growing near $B$. erecta but is known only from areas in the northwest portions of the range of that species, and in trans-Pecos Texas and adjoining New Mexico it is a frequently collected plant in an area from which $B$. erecta is unknown. The plants of $B$. intermedia are seldom $5 \mathrm{dm}$. tall and are usually lower and much branched near the base, with the elongate branches loosely ascending. Young plants are 
erect; old ones tend to become decumbent. The fruits are borne on subequal pedicels forming tidy long-peduncled umbels, readily distinguished from the looser imperfectly umbellate inflorescences of B. erecta. The inflorescence of $B$. erecta is a cymose panicle in which many of the branchlets become more or less crowded and bear their fruits in a subumbellate arrangement. Associated with the subumbellate clusters in the inflorescence of $B$. erecta are branched, irregular, and more open groupings of fruit that are evidently cymose. Even the subumbellate clusters have the fruits borne on pedicels of unequal length that are produced at different levels below the apex of the common axis. Furthermore, in these subumbellate clusters 2 or 3 fruits may be borne on a single "pedicel." The compact neat umbels of $B$. intermedia are stable units in a fixed type of inflorescence and readily serve to distinguish that species from $B$. erecta.

Boerhavia spicata Choisy in DC. Prodr. $13^{2}: 456$ (1849).

Boerhavia spicata var. Torreyana Wats. Proc. Am. Acad. 24 : 70 (1889).

Boerhavia Torreyana (Wats.) Standl. Contr. U. S. Nat. Herb. 12: 385 (1909).

Boerhavia Coulteri (Hook.) Wats. Proc. Am. Acad. 24: 70 (1889).

Boerhavia Rosei Standl. Contr. U. S. Nat. Herb. 13: 424 (1911).

Boerhavia Watsoni Standl. Contr. U. S. Nat. Herb. 12: 384 (1909).

Coahuila: Red dunes at Tanque Colorado, stems ascending, Johnston 8657; Torreon, sandy places along Rio Nazas, 1898, Palmer 488. Chinuahua: $10 \mathrm{~km}$. south of Escobillas, frequent on sandy slope, stems ascending, fl. purple, Stewart 2355; Chihuahua, 1935, LeSueur 388.

Central Texas to southeastern California and south into our area and along the Pacific Coast to Sinaloa. An annual growing in sandy places. A species readily recognized by its racemose fruiting inflorescences, its minute corollas, and the inconspicuous bracts subtending the fruit.

Boerhavia Wrightii Gray, Am. Jour. Sci. II. 15: 322 (1853).

Boerhavia bracteosa Wats. Proc. Am. Acad. 20:370 (1885).

CoAhuila: Las Margaritas, west side of Valle Delicias, frequent in sandy arroyo, ascending, Stewart 2947. Chinuahua: 5 mi. southeast of San Carlos, gravelly bank of small arroyo, erect, corolla white, pink outside towards the base, Johnston \& Muller $80 ; 8$ mi. north of San Lucas, road to Chihuahua, fl. white, White $2323 ; 3$ mi. north of Charca Piedra (21 mi. northeast of Camargo), erect, under bushes on silty plain, Johnston 7930 .

Trans-Pecos Texas to southeastern California and adjoining northern Mexico, reaching its southern limit in our area. An annual herb, readily recognized by its prevailingly 4 -angulate fruits and the conspicuous bracts on the elongating racemose inflorescence.

Boerhavia purpurascens Gray, Am. Jour. Sci. II. 15: 321 (1853).

Reported from "Near Chihuahua, 1887, Palmer 1582" by Standley, Contr. U. S. Nat. Herb. 13: 425 (1911). Otherwise known only from Arizona and western New Mexico. A well-marked species related to $B$. Wrightii, from which it is distinguished by its usually 5-angulate fruits and non-elongating dense glomerate clusters of flowers and fruit, which are interspersed with evident persistent glandular-villous bracts.

Cyphomeris crassifolia Standl. Contr. U. S. Nat. Herb. 13: 428 (1911).

Coahuila: $2 \mathrm{mi}$. northwest of Frontera, road to Natadores, silty desert plain, 
6-12 inches tall, Johnston 7178; Saltillo, one plant, near river, 2 ft. tall, 1898, Palmer 172 (ISOTYPE).

Known only from eastern Coahuila and Nuevo Leon. Very closely related to $C$. gypsophiloides but apparently distinguishable by its triangularovate sinuate or sinuately lobed leaf-blades and densely puberulent stems and leaves.

Cyphomeris gypsophiloides (M. \& G.) Standl. Contr. U. S. Nat. Herb. 13:428 (1911).

Vernacular name: Pega mosca.

Coahuila: Sierra del Carmen, Aug. 22, 1936, Marsh 578; La Azufrosa, 3 ft. tall, abundant, Sept. 22, 1848, Gregg 513; Saltillo, three plants under bushes on shady embankment, stems sticky, 1898, Palmer 171; Rancho El Pino, northwest of Sierra del Pino, in mogote, Stewart 1783; Cañon Ybarra, Sierra del Pino, arroyo bank, Stewart 1894; La Noria, Sierra del Pino, sprawling, shaly arroyo-bank, Johnston \& Muller 508; Sierra del Pino, mouth of southern Canyon, hillside, Stewart 1192; San Antonio de los Alamos, gravelly shaded canyon floor, Johnston \& Muller 884; Sierra Hechiceros, Cañon Indio Felipe, Stewart 50, 67, Johnston \& Muller 1333; Sierra Almagre, rocky places in deep shaded canyon, Johnston \& Muller 1185; Sierra Mojada, Cañon Hidalgo, hillside below crest, Stewart 1086; La Botica, Valle Delicias, Stewart 2854, 2944; Sierra Parras, Oct. 1910, Purpus 4956, 4957; San Lorenzo de la Laguna, 1880, Palmer 1125. Chinuahua: Sierra Rica, Cañon Madera, dry arroyo bank, Stewart 2443; Santa Eulalia Hills, 1885, Wilkinson; rocky hills near Chihuahua, limestone ledges, Aug. 1885, Pringle 693.

Southeastern New Mexico, trans-Pecos, central, and southern Texas, and south in Chihuahua, Coahuila, Tamaulipas, and Hidalgo to Oaxaca. A perennial with slender brittle stems that are sprawling, ascending, or erect. It is rarely common. Usually growing in rocky soil and frequently scrambling in low bushes. The perianth is purplish, magenta, pink, and, not uncommonly, even white. The foliage varies from lance-linear to lanceolate and from completely glabrous and lustrous to somewhat puberulent and even sparsely glandular, especially when young. The type was collected in Tehuacan, Puebla. The specific name is inappropriate.

Cyphomeris gypsophiloides var. Stewartii var. nov.

A varietate typica differt caulibus et foliis glandulosis, pilis minutis glanduliferis abundanter obsitis.

Chinuahua: Sierra Diablo, $3 \mathrm{~km}$. east of Cañon Rayo, open hillside, not common, $1 \mathrm{~m}$. tall, fl. white, Stewart 941; Sierra Diablo, mouth of Cañon Rayo, arroyo bank, not common, $12 \mathrm{dm}$. tall, fl. violet, Stewart 941; large canyon near northeast end of Sierra Diablo, 1 m. tall, July 29, 1941, Stewart 1943 (TYPE, Gray Herb.); Cañon Coyote, south end of Sịrra Diablo, $20 \mathrm{~km}$. northwest of Santa Fe, dry arroyo, ascending, fl. purple, Stewart 2612.

This robust very glandular variety is known only from the Sierra Diablo in extreme southeastern Chihuahua. It may deserve specific rank. However, some plants of $C$. gypsophiloides from southwestern Coahuila appear to be transitional to the variety, having a robust habit and scattered glands on the foliage.

Commicarpus scandens (L.) Standl. Contr. U. S. Nat. Herb. 12: 373 (1909).

Boerhavia scandens L. Sp. Pl. 3 (1753).

Coahuila: Sierra Hechiceros, Cañon Indio Felipe, along creek banks, Stewart 25, 108; San Antonio de los Alamos, sprawling among rocks at base of cliffs, Johnston $\mathcal{E}$ 
Muller 881; Cañon del Agua Grande, Sierra Sobaco west of Las Delicias, on gypsum near water, $1 \mathrm{~m}$. tall, Stewart 2811. Chinuahua: Sierra Organos, 1937, LeSueur 1396; Aldama, shady woods along water ditch, scarce, stems long, fl. greenish yellow, 1908, Palmer 241.

From trans-Pecos Texas (Presidio County, in canyons along the Rio Grande) and southern Arizona south through Mexico; West Indies; northwestern South America. In Mexico best known from the western and southern parts of the country. Standley reports that it behaves as an introduced ruderal weed on the west coast of Mexico. In our area, however, the plant is seemingly native, rare, and not at all aggressive.

Anulocaulis eriosolenus (Gray) Standl. Contr. U. S. Nat. Herb. 12:375 (1909).

Boerhavia eriosolena Gray, Am. Jour. Sci. II. 15: 322 (1853).

Vernacular names: Pegajosa; "Pea monte."

Coahuila: $4 \mathrm{mi}$. west of Cuatro Cienegas, stony slope, fl. pink, Johnston 7155; near Azufrosa, 3 ft. tall, fl. pale red, Sept. 22, 1848, Gregg 512 (TYPE) ; 55 mi. west of Saltillo (23 mi. east of Paila), about rocks on steep sandstone slope, Johnston 7701; 14 mi. east of Paila, Shreve \& Tinkham 9894; south end of Cañada Oscuro near Tanque La Luz, confined to gypsum beds on escarpment, 1-4 ft. tall, fl. purple, not common, Johnston 8493; ascent to Sierra Fragua east of Tanque Colorado, local on banks of cemented gravel, fl. red, 3-6 ft., Johnston 8810; valley between La Vibora and Matrimonio Viejo, confined to gypsum beds, 1-4 ft. tall, frequent, fl. pink, Johnston 9344; 2 km. southeast of Noria San Juan (southeast of Laguna del Rey), plains, common, fl. purple, Stewart 2658; 16 mi. south of Laguna del Rey, gypsum plains, 1-4 ft., Johnston 7813; Rancho Las Uvas, gypsum slopes on east side of Valle Acatita, scarce, fl. purple, Stewart 2727; San Lorenzo de la Laguna, 1880, Palmer 1124; Viesca, March 1905, Purpus 1053.

Known to me only from Coahuila and Brewster County, Texas. Standley, Contr. U. S. Nat. Herb. 13: 430 (1911), reports a collection from Torreon made by Purpus in 1903. Torrey, Bot. Mex. Bound. 172 (1859), reports collections from "gravelly plains near Presidio del Norte [Ojinaga], and below the Great Cañon of the Rio Grande." The latter station may be the canyons in the Big Bend. The report from Ojinaga $\mathrm{I}$ have been unable to verify. The only member of the genus I have seen from about Ojinaga is $A$. reflexus.

The species appears to be a gypsophile and confined to pure gypsum or mixed gypseous soils. It is very distinct, differing from its congeners in the conspicuously villous tube of its pink perianth and in the calyx-like involucre of 4-6 tardily deciduous subscarious bracts which subtends each flower. The root is apparently biennial and never forms a gnarled and woody caudex. The fruit is turbinate with the summit broadly obtuse or retuse. The glutinous bands at the middle of the stem-internodes are conspicuously developed. The stems and leaves are usually flushed with pink or rose.

Anulocaulis leiosolenus (Torr.) Standl. Contr. U. S. Nat. Herb. 12: 375 (1909).

Boerhavia leiosolena Torr. Bot. Mex. Bound. 172 (1859).

Texas (Hudspeth Co.): Gypsum quarry east of Finlay, weathered gypsum, Waterfall 5026; Great Canyon of the Rio Grande, Bigelow.

The type of this species was collected "In gypseous soil, Great Cañon of the Rio Grande, 70 miles below El Paso, June; Parry," or, in other 
words, at the canyon of the Rio Grande a mile or so below Indian Hot Springs in southern Hudspeth Co., Texas. The species is naturally to be expected in adjoining portions of Chihuahua.

Anulocaulis leiosolenus var. lasianthus var. nov.

A varietate typica differt perianthiis praesertim in alabastro extus distincte puberulentibus vel villosulis, haud glabris.

TeXas (Brewster Co.): Hot Springs, 1937, Warnock 701A; 51/4 mi. east of Terlingua, Sept. 24, 1938, Cory 30251 (TYPE, Gray Herb.).

Known only from the Big Bend, but occurring near the Rio Grande at Hot Springs and consequently to be expected in adjoining Coahuila. Apparently an isolated eastern race of $A$. leiosolenus distinguishable only by its hairy perianths, It is separated from typical $A$. leiosolenus by the whole of Presidio County, Texas, an area in which the genus is represented only by A. reflexus. As with the species, the variety is probably also gypsophilous.

Anulocaulis reflexus sp. nov.

Planta perennis erecta $3-10 \mathrm{dm}$. alta e caudice lignoso erecto erumpens; caulibus pluribus glaberrimis pallidis rigide ascendenterque ramosis nullo modo glutinosis; foliis e partibus inferioribus caulis et ramorum infimorum in jugis 2-4 et 5-15 cm. longe distantibus gestis, oppositis coriaceis in sicco rigidis et fragilibus; lamina cordata vel cordato-reniformi $4.5-9 \mathrm{~cm}$. lata $4-11 \mathrm{~cm}$. longa, apice acuta vel obtusa vel rotunda, basi sinu $4-11 \mathrm{~mm}$. profundo donata, margine plus minusve irregulariter sinuata obtuse denticulata brunnea glandulari-incrassata, pagina utraque plus minusve abundanter glanduloso-tuberculata (tuberculis brunneis praesertim eis paginae superioris laminae minute et sparse villosulis); floribus nodis inflorescentiae laxe dispositis haud congestis; perianthio rosaceo, tubo non raro plus minusve curvato ca. $1 \mathrm{~cm}$. longo basim versus ca. $1 \mathrm{~mm}$. crasso, deinde sursum gradatim ampliato apice ca. $2.5 \mathrm{~mm}$. crasso, lobis 5 oblongis $5-10$ $\mathrm{mm}$. longis ca. $2.5 \mathrm{~mm}$. latis deflexis; perianthiis post anthesi subtubulosis rectis $10-14 \mathrm{~mm}$. longis persistentibus; staminibus inaequalibus $3 \mathrm{ca} .1 \mathrm{~cm}$. longe exsertis; anthocarpio turbinato $6 \mathrm{~mm}$. longo ad $4.5 \mathrm{~mm}$. diametro, medio annulo incrassato anguste alato circumcincto, parte inferiore conico 5-costato, parte superiore majore conico-hemisphaerico 10-costato.

Chrmuahua: $10 \mathrm{mi}$. south of Ojinaga, silty soil along base of low hills, outwash from saline and gypsiferous clays and shales, frequent, erect, 1-3 ft. tall, Aug. 8, 1940, Johnston $\mathcal{E}$ Muller 10 (Type, Gray Herb.) ; 10 mi. south of Ojinaga, base of low hills in gypseous saline soil, fl. pink, Aug. 9, 1941, Johnston 8023; 3 mi. north of Chapo, frequent along outcrops of shales, 1-3 ft. tall, fl. purple, Sept. 23, 1940, Johnston $\mathcal{E}$ Muller 1440. TExAs: South end of Van Horn Mts., about $11 \mathrm{mi}$. southwest of Chispa, gypseous shale ridge, Jeff Davis Co., July 26, 1943, Waterfall 5296; Old Newman Spring, just east of San Carlos Creek one mile north of Weatherford's, shrubby at base, fl. fresh pink, filaments long-protruding and showy, Presidio Co., June 11, 1941, Hinckley 1665.

A well-marked species, probably most closely related to A. leiosolenus. Readily distinguished from all its congeners by having the limb and lobes of its perianth reflexed. In previously described species of this genus the limb of the perianth is funnel-form and its lobes are ascending. In $A$. reflexus the throat is exvaginate, being inside out and reflexed and sheathing the upper 1-3 mm. of the perianth-tube. The lobes, short to elongate, 
are strongly reflexed and parallel the commonly somewhat curved tube. The stamens consequently are very long-exserted and conspicuous. After anthesis the limb and its lobes shrink to form a tumid margin to the subtubular perianth-tube, which remains attached and erect for some time on the ripening fruit.

It is a curious fact that the known stations for A. reflexus lie in an area along the Rio Grande between the districts in which A. leiosolenus and its var. lasianthus are known. The species probably ranges southwest into Chihuahua, for while traveling by railroad from Chihuahua to Ojinaga in 1941 I observed an Anulocaulis, most likely this species, on the extensive gypsum beds just west of the Rio Conchos.

Mirabilis linearis (Pursh) Heimerl, Ann. Cons, et Jard. Bot. Genève 5: 186 (1901).

Allionia linearis Pursh, Fl. Am. Sept. 728 (1814).

Oxybaphus linearis Robins. Rhodora 10:31 (1908).

Allionia petrophila Standl. Contr. U. S. Nat. Herb. 12: 340 (1909).

CoAhuila: Sierra Encantada, mouth of Cañon San Enrique, bank of dry arroyo, erect, fl. lavender, Stewart 1377; base of Sierra Guajes, $7 \mathrm{~km}$. east of Rancho Buena Vista, limestone hillside, erect, fl. reddish white, Stewart 1477; Valle de los Guajes, $10 \mathrm{~km}$. south of Rancho Buena Vista, grassy hillside, erect, $1 \mathrm{~m}$. tall, fl. purplish white, Stewart 1362; Valle de los Guajes, $20 \mathrm{~km}$. south of Rancho Buena Vista, grassy flat, erect, fl. orchid, Stewart 1335; Sierra del Pino, ridge west of La Noria, erect, fl. burntorange or red, Johnston $\mathcal{E}$ Muller 611, 617; Sierra del Pino, flats at La Noria, fl. whitish, Johnston $\mathcal{E}$ Muller 426; tableland north of Cañon Cuervo Chico, slopes of low limestone hill, decumbent on grassy slope, Johnston 8555 ; south base of Sierra Hechiceros, $6 \mathrm{~km}$. east of El Tule, open flat, fl. orchid, Stewart 483. Chrnuahua: High valley on northwest end of Sierra Diablo, hillsides and meadows, fl. purple, Stewart 964; rocky hills northwest of Chihuahua, Sept. 1886, Pringle 840 (isotype of $A$. petrophila).

Widely distributed in central parts of the United States and south through Arizona, New Mexico, and western Texas into our area.

A plant with the leaves linear or narrowly lanceolate and very gradually attenuate below into a more or less well-developed petiole. The stems and leaves are usually whitish and glabrous or practically so. The inflorescence and the involucres are usually viscid-villous with fulvous hairs. Over most of its range this species has narrow leaves rarely more than $6 \mathrm{~mm}$. wide. In Texas, however, forms with the blade wider (up to $12 \mathrm{~mm}$.) are not uncommon. Among the collections cited above, three are atypical, Stewart 1377 and Johnston \& Muller 426 having green sparsely hairy involucres and the uppermost leaves broadened at the base, and Stewart 483 having the leaves above the middle of the stem thin, green, rather broad, and with the base rounded and subsessile.

Mirabilis pseudaggregata Heimerl, Ann. Cons. et Jard. Bot. Genève 5: 183 (1901).

Mirabilis pseudaggregata f. subhirsuta Heimerl, l.c. 184.

Mirabilis pseudaggregata f. eglandulosa Heimerl, l.c. 184.

Allionia pseudaggregata Standl. Contr. U. S. Nat. Herb. 12: 356 (1909).

Allionia pseudaggregata subhirsuta Standl. Contr. U. S. Nat. Herb. 12:356 (1909).

Oxybaphus pseudaggretatus Weatherby, Proc. Am. Acad. $45: 425$ (1910).

Coahulla: Sierra Hechiceros, Cañon Indio Felipe, base of talus slope, Stewart 34; $7 \mathrm{mi}$. south of Jaco, in shade inside mogote, Johnston \& Muller 1117. Chinuahua: Hills northeast of Chihuahua, cool slopes, Aug. 30, 1886, Pringle 793 (ISOTYPE). 
A light green, sprawling, much-branched plant with very scanty and inconspicuous pubescence and abundant narrowly lanceolate leaves, which are gradually attenuated below into a distinct petiole. The leaves in form, size, texture, and color are similar to broad-leaved forms of $M$. linearis found in trans-Pecos Texas. It is possible that $M$. pseudaggregata may be merely a shade form of $M$. linearis. Most of its flowers are cleistogamic. It differs from $M$. linearis in its leafy elongate slender much branched sprawling stems and its scantily pubescent inflorescence and involucres. From $M$. attenuata, of central Mexico, it differs in its thinner more attenuate and more distinctly petiolate leaves and scanty pubescence. I know $M$. pseudaggregata only from the collections cited above.

Mirabilis glabra (Wats.) Standl. Field Mus. Publ. Bot. 8: 304 (1931).

Oxybaphus glaber Wats. Am. Nat. 7:301 (1873).

Allionia glabra Kuntze, Rev. Gen. 2: 533 (1891).

Oxybaphus glaber var. recedens Weatherby, Proc. Am. Acad. 45: 425 (1910).

Allionia glabra recedens Standl. Contr. U. S. Nat. Herb. 13: 406 (1911).

Chinuahua: Sandhills south of Samalayuca, Sept. 20, 1886, Pringle 1126; dunes near Samalayuca, 1935, LeSueur 390; between Casas Grandes and Sabinal, 1899, Nelson 6351 (type of var. recedens).

Southern Utah to northern Chihuahua. A relative of $M$. linearis, differing in its glabrous or nearly glabrous stems, leaves, and fruit. The involucre is rather small, single-flowered, glabrous or nearly so, and more deeply lobed and less spreading than in $M$. linearis. In recognizing the species I am emphasizing the characters of the involucre and the associated glabrous fruit. Standley seems to have admitted to this species some plants which I would classify as glabrous-fruited $M$. linearis.

Mirabilis coahuilensis (Standl.) Standl. Field Mus. Publ. Bot. 8: 305 (1931).

Allionia coahuilensis Standl. Contr. U. S. Nat. Herb. 12: 347 (1909).

Oxybaphus coahuilensis Weatherby, Proc. Am. Acad. 45: 425 (1910).

Coahuila: Sierra Gloria, Marsh 1908; Saltillo, 1898, Palmer 158 in pt. (ISotype); Sierra Madera, Cañon del Agua, open oak woods, Muller 3246A; Sierra Madera, Cañon Charretera, in oak thicket, erect, Johnston 8942, 9137; central Sierra del Pino, head of Cañon Ybarra, dry hillside, erect, Stewart 1259; Cañon del Cuervo Chico, among bushes, Johnston 8509; Parras, 1880, Palmer 1113. Chinuahua: Sierra Rica, Cañon Madera, Stewart 2460, 2498, 2498A; $12 \mathrm{~km}$. north of Escobillas, rocky slope in bushes, Stewart 2379; mountains northwest of Chihuahua, 1936, LeSueur 615. Durango: Near Pasaje, fl. purple, Shreve 9125. Nuevo Leon: Arroyo Hondo, Hac. San José de Raices, Mueller 2287A; between Cieneguillas and Puerto Santa Ana, 15 mi. southwest of Galeana, Mueller 914; between Encinal and Pablillo, about $15 \mathrm{mi}$. southwest of Galeana, Mueller 1049. Texas: High rocky hills of the Pecos (western Crocket Co.?), June 1, 1851, Wright s. n.; Chisos Mts., Aug. 1883, Havard 67; Mt. Emory, Chisos Mts., Cory 7132; near Boot Springs, Chisos Mts., Cory 7305, Mueller 7995, Moore \& Steyermark 3180; Mt. Livermore, Davis Mts., Aug. 1935, Hinckley.

Western Texas south through our area into Durango and Nuevo Leon. An erect plant with lanceolate leaves which are abruptly contracted into distinct petioles. Even the uppermost leaves have short petioles. The leaves of the middle stem commonly have petioles a centimeter long, sharply set off from the obtuse, rounded, or broadly acute base of the blade. Most plants are glandular and pubescent in the inflorescence and inconspicuously harry or glabrous below. The type collection is unusual 
in being conspicuously viscid-villous and tawny down to below the middle of the plant. Fosberg, Lloydia 4:281 (1941), reports, sub M. aggregata, some excessively hairy plants similar to the type of $M$. coahuilensis, among Muller's collection (no. 3246) from Cañon del Agua in the Sierra Madera. Most of Muller's collection represented the common nearly glabrous form of the species.

Mirabilis oblongifolia (Gray) Heimerl, Ann. Cons, et Jard. Bot. Genève 5: 183 (1901), Oxybaphus nyctagineus var. oblongifolius Gray in Torr. Bot. Mex. Bound. 174 (1859).

Allionia oblongifolia Small, Fl. S. E. U. S. 407 (1903).

Allionia Greggii Standl. Contr. U. S. Nat. Herb. 12:347 (1909).

CoAhuila: Sierra del Carmen, Sept. 1, 1936, Marsh 882; Sierra del Carmen, Cañon Sentenela, Wynd \& Mueller 622; San Antonio de las Alanzanas, frequent, $2 \mathrm{ft}$. tall, fl. red, Gregg 348; Carneros area, 1880, Palmer 111; mountains 24-26 km. northwest of Fraile, Stanford et al. 400, 448. Chiнunhua: Sierra Almagre, decumbent in leafmould in deep shaded canyon, Johnston \& Muller 1180. Nuevo Leon: Near Monterrey, 1933, Mueller 283. TE^as: Near Del Rio, "prairies of the San Felipe," Val Verde Co., July 11, 1849, Wright 604 (TYPE) ; Del Rio, along San Felipe Creek, Cory 8968; Altuda Mt., upper canyons, Ord Mts., Brewster Co., limestone, 1940, Warnock 32; Blue Creek, Chisos Mts., Cory 6989, Moore E Steyermark 3342; "Mountains of Cibola" (Chinati Mts.), Presidio Co., Bigelow; Chinati Mts., 1881, Havard 98.

I have associated under the present species a group of plants ranging from western Texas south through our area into Nuevo Leon. The plants are loosely branched, with ascending or decumbent stems, and are usually dusky and glandular throughout. The distinctly petiolate leaves are ovate or broadly oblong and have a broadly obtuse or cordate base. Most plants have at least a few distinctly cordate leaf-bases. Most of them appear to come from sheltered canyons and slopes and their characteristic glandularity is not readily explained away as a xerophytic modification. Their loose habit and rather thin broadish leaves are suggestive of a shaded habitat.

Perhaps also to be included in $M$. oblongifolia is the type of Allionia comata Small, Fl. S. E. U. S. 407 (1903), which was collected by Wright (no. 1718), Aug. 20, 1851, on the stony hills near the Coppermines, in Grant Co., New Mexico. This has the loose habit, dark color and glandularity, and rather thin leaves of the Coahuilan plants, but the leaves, though broadly ovate and petiolate, are not distinctly cordate at the base. I suspect, however, that it is only an aberrant shade form of the distinctive Arizonan and New Mexican plant described by Standley as Allionia pratensis and A. melanotricha, which Wright also collected about the Coppermines.

Mirabilis sp.

Coahuila: San Antonio de los Alamos, base of the tuff cliffs on talus, Johnston 8274; highest peaks of the Sierra Cruces, open rocky hillside, Stewart 1146; north end of the Bolson de los Lipanes, west of Rancho Leja, among cacti, Johnston \& Muller 1256.

The three collections cited form a uniform series and probably represent an undescribed species allied to $M$. oblongifolia and $M$. coahuilensis. They are pale green plants with a very inconspicuous pubescence and scarcely any glandularity. They have ovate cordate long-pediceled leaf-blades. Super- 
ficially they are most suggestive of $M$. glabrifolia in habit, but upon close inspection differ in having hairy strongly ribbed non-tuberculate fruit, more sparsely pubescent inflorescence, the stem leafy up to the inflorescence, and rather large perianths.

Mirabilis glabrifolia (Ort.) comb. nov.

Calyxhymenia glabrifolia Ortega, Nov. Pl. Dec. 1: 5. t.1 (1797).

Mirabilis corymbosa Cav. Icones $4: 55$. t. 379 (1798).

Allionis corymbosa var. texensis Coulter, Contr. U. S. Nat. Herb. 2: 351 (1894).

Allionia texensis Small, Fl. S. E. U. S. 406 (1903).

? Allionia deltoidea Standl. Contr. U. S. Nat. Herb. 13: 405 (1911).

Coahuila: Saltillo, summit of stony mountain, fl. pink, Palmer 326; valley north of Saltillo, frequent, 1-2 ft., fl. reddish purple, Sept. 19, 1848, Gregg 445; Cañon Milagro, Sierra Guajes, $12 \mathrm{~km}$. west of Hac. Encantada, shade in canyon, fairly common, fl. orchid, Stewart 1732; Cañon Ybarra, Sierra del Pino, arroyo, erect, fl. lavender or purplish, Stewart 1831, 1913; Sierra del Pino, mouth of main south canyon, hillside, erect, fl. orchid, Stewart 1190; west base of Picacho del Fuste, gravelly flat, erect, among bushes, Johnston 8350; Sierra Mojada, Cañon Hidalgo, open slope below crest, erect, fl. purple, Stewart 1089; mouth of Cañon Blanco, north end of Valle Delicias, arroyo banks, erect, fl. purple, Stewart 2903; Parras, 1880, Palmer 1112; Sierra Parras, Oct. 1910, Purpus 4688; Sierras Negras, 9 km. south of Parras, Stanford et al. 207; summit of Picacho de Jimulco, Stanford et al. 97 . Chinuahua: $10 \mathrm{~km}$. south of San José del Progreso, south end of Sierra Seca, silty slope, frequent, Stewart 2298; Sierra Santa Eulalia, Sept. 19, 1885, Pringle 542. ZacateCAS: Mountain $18 \mathrm{~km}$. west of Concepcion del Oro, Stanford et al. 567, 567 A. Texas: North base of the Eagle Mts., Hudspeth Co., Sept. 3, 1849, Wright 605 (isotype of var. texensis).

From trans-Pecos Texas south through our area to southern Mexico. A perennial with a few erect slender stems, commonly supported by bushes. The leaves are borne below the middle of the stem and are frequently crowded at the base. They are long-petiolate and have an ovate or oblong blade which is usually glabrous and has a truncate, rounded, or strongly cordate base. The fruit is tuberculate and glabrous.

Past writers have consistently accepted the name "corymbosa" for this species and as consistently cited Ortega's Calyxhymenia glabrifolia as a synonym. However, in the paragraph preceding that in which he published $M$. corymbosa, Cavanilles states that Ortega's work was already published. Calyxhymenia glabrifolia Ort. undoubtedly has priority over Mirabilis corymbosa Cav. Both were based on plants growing in the Royal Botanic Garden at Madrid during the summer of 1797.

I have not seen any authentic material of Allionia deltoidea Standl., a species based upon Nelson 3823, collected in Aug. 1898, at La Ventura, Coah. The original description fits the present species reasonably well. Standley, No. Am. Fl. 21: 229 (1918), in a later work, treated A. deltoidea as a synonym of $A$. ciliata. Unless the original description is grossly inaccurate this must be a mistake.

Mirabilis rotata (Standl.) comb. nov.

Allionia rotata Standl. Contr. U. S. Nat. Herb. 12: 347 (1909).

Oxybaphus rotatus Weatherby, Proc. Am. Acad. 49: 492 (1913).

Coahuila: La Azufrosa, scarce, 2 ft. tall, Sept. 22, 1848, Gregg 511 (ISotype); San Antonio de los Alamos, shelter of tuff-cliffs, erect, Johnston \& Muller 890; Picacho de San José, dry arroyo bank, erect, Johnston \& Muller 815; Laguna del Rey, gypsum 
on plain, scarce, erect, Stewart 3016; north of Puerto Ventanillas, south of Las Delicias, in arroyo, scarce, erect, fl. purple, $45 \mathrm{~cm}$. tall, Stewart 2791. Chinuahua: Sierra Diablo, near mouth of Cañon Rayo, dry open hillside, $7 \mathrm{dm}$. tall, not common, fl. purplish, Stewart 934. Texas: Fresno Canyon, 4-5 mi. above Arroyo Segundo, southeastern Presidio Co., a few plants sheltered by shrubs on flat, Hinckley 2277.

Known only from Coahuila and adjoining Chihuahua and Texas. Closely related to $M$. glabrifolia but a more herbaceous somewhat succulent plant, glandular-pubescent throughout and with a glandular-puberulent fruit roughened by very prominent dorsiventrally flattened tuberculations. The tuberculations on the angles of the fruit are very suggestive of diminutive shelf-fungi. In his latest work on the genus, Standley, No. Am. Fl. 21: 219 (1918), cited the present species as a synonym of $M$. viscosa Cav. Mirabilis rotata might possibly be dismissed as a variety of $M$. glabrifolia, but it can not be identified with $M$. viscosa, for that is a coarse bushy annual with a paniculate inflorescence that consists of a straight indeterminate axis bearing numerous opposite floral branches. The present species has the habit of $M$. glabrifolia, producing from a perennial root a few subsimple slender stems terminated by a forking somewhat corymbose inflorescence.

Mirabilis Jalapa L. Sp. Pl. 177 (1753).

Vernacular Name: Maravilla.

Coahuila: Palm Canyon, Mariposa Ranch, Sept. 19, 1936, Marsh 977A; San Antonio de las Alanzanas, 2 ft. tall, frequent, fl. red, Aug. 31, 1848, Gregg 344.

Warmer regions of America, a Mexican species now widely dispersed as a garden plant and as an escape from cultivation. The cited specimens seem to agree with the commonly cultivated form of the species and probably are escapes from cultivation. Gregg, however, notes on his collection that it was "evidently a wild plant." In any case the Texan var. Lindheimeri (Standl.) Cory, native along the escarpments of the Edwards Plateau and readily recognized by its broad leaves, can be expected indigenous in northern Coahuila.

Mirabilis longiflora L. Sv. Vet.-Akad. Handl. 1755: 176 (1755).

Mirabilis Wrightiana Gray ex Britt. \& Kearney, Trans. N. Y. Acad. 14: 28 (1894).

Mirabilis Wrightiana var. tubiflora Heimerl, Notizbl. Bot. Gart. Berlin 11:450 (1932).

Mirabilis longiflora var. Wrightiana Kearney \& Peebles, Jour. Wash. Acad. 29:475 (1939).

Vernacular Name: Maravilla.

Coahuila: Sierra del Carmen, Cañon Sentenela, Wynd E Mueller 585; canyon above Palomas, northeast of Saltillo, vine-like, $3 \mathrm{ft}$. tall, scarce, fl. white, Aug. 31 , 1848, Gregg 331; escarpment above mines on west side of Potrero de la Mula, one colony on sunny ledge just below crest, Johnston 9246; Sierra Hechiceros, Cañon Indio Felipe, shady places, 4-10 dm. tall, fl. white, Stewart 68, 114; Sierra Mojada, Cañon Calabasa, shade in deep canyon $100 \mathrm{~m}$. below crest, erect, Stewart 2208. Chinumua: Sierra Rica, Cañon Madera, shade on slope, fl. white, Stewart 2501; $7 \mathrm{mi}$. northwest of Temporales de Honorato, in mogote, loosely branched, up to $2 \mathrm{~m}$. tall, perianth white, anthers magenta, Stewart \& Johnston 1986; high valley on northwest end of Sierra Diablo, slopes, 4-11 dm. tall, fl. white, Stewart 960.

Arizona to trans-Pecos Texas south into our area and along the eastern and western Sierra Madre to southwestern Chihuahua and southwestern 
Tamaulipas; reappearing in central and southern Mexico. Standley, Contr. U. S. Nat. Herb. 13: 416-17 (1911), reports the plant from Gallejo Spring, between Chihuahua and El Paso (Wislizenus 122), and from the "Santa Eulalia Plains" (Wilkinson). A leafy much-branched herb with elongate ascending stems, usually found in thickets. The elongate trumpet-shaped perianth is white. It appears to be an uncommon plant in our area. Our collections are referable to var. Wrightiana, the northern form, differing from the typical plant of central Mexico in its smaller much less glandular more distinctly petiolate leaves and somewhat smaller perianths with a more slender and less glandular tube.

Mirabilis multiflora (Torr.) Gray in Torr. Bot. Mex. Bound. 173 (1859).

Quamoclidion multiflorum Torr. ex Gray, Am. Jour. Sci. II. 15:321 (1853).

Coahulla: Hillcoat Mesa lying west of Encantada Ranch, July 25, 1938, Marsh 1464A; west slopes of the Sierra del Carmen, $8 \mathrm{~km}$. northeast of Hac. Encantada, common on grassy flats, erect, fl. lavender, Stewart 1573; high mesa $4 \mathrm{~km}$. north of Rancho Buena Vista, grassy flat, prostrate, not common, fl. orchid, Stewart 1448. Chinuahua: Samalayuca, 1935, LeSueur 396; hills northeast of Chihuahua, Aug. 13, 1885, Pringle 547.

Utah and Arizona east to Colorado and trans-Pecos Texas, and south in Chihuahua, Coahuila, and Nuevo Leon.

Mirabilis oxybaphoides Gray in Torr. Bot. Mex. Bound. 173 (1859).

Allioniella oxybaphoides Rydb. Bull. Torr. Bot. Cl. 29: 687 (1902).

Mirabilis oxybaphoides f. glabrata Heimerl, Ann. Cons. et Jard. Bot. Genève 5: 180 (1902).

Coafulla: Sierra del Pino, crest of high ridge west of La Noria, among low bushes, very glutinous, fl. pink, Johnston $\mathcal{E}$ Muller 603; Sierra Mojada, Cañon Calabasa, shaded places in deep canyon $100 \mathrm{~m}$. below crest, prostrate, fl. white, Stewart 2209.

From Arizona, southern Colorado, and trans-Pecos Texas south into Coahuila. The plant from the Sierra del Pino, growing on an exposed ridge, is distinctly hairy and glandular and has thickish grayish leaves $15-30 \mathrm{~mm}$. wide. The material from Sierra Mojada, growing in a shaded canyon, is practically glabrous and has thin green leaves $40-60 \mathrm{~mm}$. wide. The two collections represent the extremes in this variable species. The species was based on Wright 596 and 1721, consisting of material collected Sept. 12, 1849, on mountains near El Paso, on Oct. 14, 1849 about large rocks apparently near Hueco Tanks, El Paso Co., Texas, and on Oct. 5, 1851, in mountain-ravines on apparently the east side of Guadalupe Pass in Hidalgo Co., southwestern New Mexico. All represent the form of the species with large green thin very sparsely pubescent leaves. Heimerl's var. glabrata, accordingly, represents the typical form of the species.

Abronia carnea Greene, Pittonia $3: 343$ (1898).

Abronia cycloptera sensu Standley.

Chinuahua: Near Juarez, sandhills, May 5, 1885, Pringle 75.

Southern New Mexico, adjacent Texas, and adjoining Chihuahua; sandy places. The name "Abronia cycloptera Gray," currently applied to the present species, is merely a renaming of $A$. micrantha Torr. Standley, Contr. U. S. Nat. Herb. 12:329 (1909), recognized this fact, but, because Gray's binomial was familiar to him, he deliberately retained it for our 


\section{$2 \mathrm{BHL}$ Biodiversity Heritage Library}

Johnston, Ivan M. 1944. "Plants of Coahuila, eastern Chihuahua, and adjoining Zacatecas and Durango, V." Journal of the Arnold Arboretum 25(2), 133-182. https://doi.org/10.5962/bhl.part.15298.

View This Item Online: https://www.biodiversitylibrary.org/item/33601

DOI: https://doi.org/10.5962/bhl.part.15298

Permalink: https://www.biodiversitylibrary.org/partpdf/15298

\section{Holding Institution}

Missouri Botanical Garden, Peter H. Raven Library

\section{Sponsored by}

Missouri Botanical Garden

\section{Copyright \& Reuse}

Copyright Status: In copyright. Digitized with the permission of the rights holder.

Rights Holder: Arnold Arboretum of Harvard University

License: http://creativecommons.org/licenses/by-nc-sa/3.0/

Rights: https://biodiversitylibrary.org/permissions

This document was created from content at the Biodiversity Heritage Library, the world's largest open access digital library for biodiversity literature and archives. Visit BHL at https://www.biodiversitylibrary.org. 